\title{
Family standards of living over the long run, England 1280-1850*.
}

\author{
Sara Horrell \\ London School of Economics
}

Jane Humphries

University of Oxford and London School of Economics

\author{
Jacob Weisdorf \\ University of Southern Denmark
}

Contact:s.h.horrell@lse.ac.uk

Department of Economic History, London School of Economics and Political Science, Houghton Street, London, WC2A 2AE

\begin{abstract}
We use new wage series for men, women and children in combination with an established cost of living index and standard assumptions about family size to construct a measure of family welfare in England, 1280-1850. We ask whether this family could achieve a standard of living historically defined as 'respectable'. We extract information from primary and secondary sources to make adjustments for the participation rates of women and children, the varying number of days worked over time, the changing involvement of married women in paid work, and the evolving occupational structure. The resulting series is the first to depict the living standard of a representative working family over the very long run. Prior to the Black Death, our family existed just above subsistence, afterwards shortage of labour brought substantial albeit not unassailable gains. Tudor era turmoil and constraints on women's work pushed the family below the 'respectable' standard. From the mid-1600s however, the gradual transformation of the economy coincided with improved welfare. Over these centuries, it was rare for men's work alone to sustain the family at a respectable level; women and children's earnings were necessary. This calls for a re-evaluation of the chronology, causes and consequences of long-run growth.
\end{abstract}

(200 words)

Word count: Text 9,752. Footnotes 2,293 
JEL classification:

N330 Economic history: labor and consumers, demography, education, health, welfare, income, wealth, religion, philosophy: Europe pre-1913

Work and welfare in Britain 1280-1860

Family living standards

Women's work

Keywords:

Living standards

Work and wages

Britain, long-run

*Acknowledgements

We would like to thank participants at NickCrafts@70 conference, hosted by CAGE at the University of Warwick, April 2019, for helpful suggestions and comments. Jacob Weisdorf thanks the Carlsberg Foundation for financial support through a 'Semper Ardens' Grant (CF18-0495). 


\section{Family standards of living over the long run, England 1280-1850}

\section{Introduction}

The effect of economic growth on living standards has long interested historians, witness the continuing debate about the effect of the British industrial revolution on wellbeing. The consequences of changes in production methods and urbanisation on wages, prices, health, literacy and customary rights have all been studied. More recently and in longer-term perspective, causal relationships have been reinterpreted with living standards themselves seen as a dynamic element in economic growth. Relatively high wage levels have been argued to underpin the 'little divergence' whereby north-western European countries pulled ahead of others in the same continent in the sixteenth century, enjoying significant commercial and manufacturing prosperity.1 In brief, the Black Death (1345-51) decimated European populations with the ensuing labour shortage rewarding survivors with unprecedentedly generous remuneration. In many countries, high wages were quickly followed by population growth that soon eroded any gains. In Britain and Holland, women's

\footnotetext{
1 Jan Luiten Van Zanden, The long road to the industrial revolution: the European economy in global perspective, 1000-1800 (Leiden, 2009); R. C. Allen, The British Industrial Revolution in Global Perspective (Cambridge University Press, 2009); R. C. Allen, 'The Great Divergence in European wages and prices from the Middle Ages to the First World War', Explorations in Economic History, 38 (2010); Stephen Broadberry, Bruce M. S. Campbell, Alexander Klein, Mark Overton, Bas van Leeuwen, British Economic Growth, 1270-1870 (Cambridge University Press, 2015).
} 
relative social and cultural autonomy and their comparative advantage and high wages in pastoral production, a sector that expanded after the Black Death, allegedly led to deferred marriage, and restrained fertility.2 Population was kept in check so that the labour's gains persisted. High wages became entrenched. In Britain, it was these same high wages, alongside the availability of cheap fuel, that centuries later motivated inventors to develop machinery that could substitute for expensive workers and persuaded employers to mechanise production. High wages, initially the product of an epidemiological catastrophe, were maintained by a gender order that restrained population growth, and so eventually caused the industrial revolution. 3

In these meta-narratives of long-run growth the evolution of wages has been key. Data has been collected on the wages of building craftsmen and building and farm labourers over time and across countries and compared to the cost of supporting a family at a 'respectable', although unchanging, level of subsistence. 4 For Britain, the data demonstrate a significant rise in the ability of these men to support a small family of four in the aftermath of the Black

\footnotetext{
${ }^{2}$ Tine de Moor and Jan Luiten van Zanden, 'Girl Power: The European Marriage Pattern and Labour Markets in the North Sea Region in the Late Medieval and Early Modern Period,' Economic History Review, 63 (2010); Jan Luiten van Zanden, Tine de Moor and Sarah Carmichael, Capital Women (Oxford University Press, 2018).
}

\section{Allen, British Industrial Revolution.}

4 Allen, 'The Great Divergence'; R.C. Allen, 'The high wage economy and the industrial revolution: a restatement', Economic History Review, 68 (2014). 
Death. Although there were subsequent periods of retrenchment, respectable wage levels reemerged associated with the related economic growth.5

However, these wage series offer only a partial perspective on the standard of living; indeed, even as descriptors of male earnings they are deeply flawed. Without exception, they are based on daily rates of pay in building trades and agricultural occupations. To move to living standards over the year then involves an assumption about the number of days worked. The conventional assumption is that this stood at 250 days per year from 1200 to 1900: a standard that has been challenged. John Hatcher has pointed out that if medieval workers were able to earn the wages observed for a full 250 days, they would have been far wealthier than their land-owning employers, a nonsensical situation.6 For a later time period, Jan de Vries has argued that increased labour market work, an 'industrious revolution', characterised the growth evident in north-west Europe which in Britain culminated in an industrial revolution.7 5 Allen, British Industrial Revolution, tables 5 and 6, figures 7 and 8, pp.428-9; Gregory Clark, 'The Long March of History: Farm Wages, Population and Economic Growth, England, 1209-1869', Economic History Review, 60 (2007); R. C. Allen and Jacob Weisdorf, 'Was there an 'Industrious Revolution' before the Industrial Revolution? An Empirical Exercise for England, c. 1300-1830', Economic History Review, 64 (2011). A respectable standard of living is defined as the man's wage being able to purchase the respectable basket of goods for his family of five people, that is, a welfare ratio of one.

6 John Hatcher, 'Unreal Wages: Long-Run Living Standards and the 'Golden Age' of the Fifteenth Century' in Commercial Activity, Markets and Entrepreneurs in the Middle Ages, edited by Ben Dodds and Christian D. Liddy (Boydell, Woodbridge, 2011).

7 Jan de Vries, The Industrious Revolution: consumer behaviour and the household economy, 1650 to the present (Cambridge University Press, 2008). 
The hypothesis of increasing industriousness has been supported by Hans-Joachim Voth's findings based on a probabilistic model of time use and evidence from London courts that the number of days worked by men increased from some 208 in 1750 to 306 by $1800-03.8$ It is very doubtful that the length of the working year was a constant 250 days.

The conventional approach also focuses exclusively on money wages. Historically, many workers received significant parts of their remuneration in kind. The provision of substantial sustenance at harvest time was both customary and efficient ensuring workers had the energy needed for the physical effort involved in getting crops in, but food and drink was oftentimes provided in other seasons too. While in-kind payments likely diminished over time, probably offset by monetary compensation, their value should be included in any account of remuneration.

Most importantly, living standards for all people, not just men, are determined at the household level; incomes and the goods they afford are shared and many commodities, such as housing, heat, and light, are largely indivisible within this unit. Unless we can assume women and children's participation rates were unchanged over time and that their monetary contributions remained at a fixed proportion of men's wages, we cannot infer material living standards without explicitly looking at the contributions of these family members.

We tackle these issues head on to provide long-run estimates of family living standards. Through a range of projects, we have collected detailed data on pay for men working on annual contracts, women on both annual contracts and day wages and for children employed

\footnotetext{
8 Hans-Joachim Voth, 'Time and work in eighteenth century England', Journal of Economic History, 58 (1998); Hans-Joachim Voth, 'The longest years: new estimates of labour input in England, 1760-1830', Journal of Economic History, 61 (2001).
} 
on a variety of payment systems all over six centuries.9 These data encompass both monetary remuneration, and, where in kinds were received, the value of such perquisites, most importantly the board and lodging received by live-in servants and journeymen. To impute monetary values to in-kinds, we resort to Robert Allen's cost of living index, a now widely accepted index of the costs of various necessities and semi luxuries that appeared in working people's expenditure baskets, as discussed in more detail below. Annual workers were paid by the year so that the amount received both in money and in kind per day in the year can be computed without assumptions about the number of days worked. Moreover, our annual series for male workers tracks the annual labour incomes earned by day as well as annual workers, but it does so based on actual days worked rather than some ahistorical and arbitrary guesstimate as to the number and so is used in the computations that follow.10 For women and children on day wages, initially we make the conventional assumption about the length of the working year, so that, for any random day in the year, remuneration will be the wage multiplied by 250 days then divided by 365 days in the year. We then combine our estimates

9 Jane Humphries and Jacob Weisdorf, 'The Wages of Women in England, 1260-1850', Journal of Economic History, 75 (2015); Jane Humphries and Jacob Weisdorf, 'Unreal Wages? Real Income and Economic Growth in England, 1260-1850', Economic Journal, https://doi.org/10.1093/ej/uez017; Sara Horrell and Jane Humphries, 'Children's work and wages in Britain, 1280-1860', Explorations in Economic History, 73 (2019).

10 If workers were homogeneous and mobile between annual and day labour, and employers were flexible in terms of the contracts offered, economic reasoning suggests that the cost and return per unit labour would be the same between across contracts and sectors. Day labourers would work just the number of days at the day rates needed to earn the salary offered to men on annual contracts, and it would be impossible to make annual employees work more days than their day working peers, see Humphries and Weisdorf, 'Unreal Wages', 
of average daily remuneration by age and gender with standard assumptions about family size and structure to obtain estimates of family income per day. However, to gauge living standards we need to evaluate the amounts and range of goods that the family income could purchase. Robert Allen's cost of living index is again of value, providing estimates of the costs over our six centuries of two alternative baskets of commodities, one delivering a barebones subsistence and one delivering a historically-defined 'respectable standard'. By dividing family income by the cost of the respectability basket in any specific year, we identify the number of such baskets the combined wages could buy, a measure of living standards, called in the literature a 'welfare ratio'. We then check the levels and trends in our welfare ratio against other historical evidence and test its sensitivity to increasingly realistic assumptions about female and child participation rates and the intensity of their labour market engagement.

Our focus is limited to material aspects of the standard of living. We lack the information with which to assess other aspects of wellbeing, such as health, environment and education. Additionally, material living standards are assessed in relation to the remuneration from labour market work. While payments in kind are included in our computations, we cannot assess other contributions to household welfare from, for example, women's domestic work. However, we do benchmark our findings against observations of the circumstances of actual families, which variously incorporate own-account agriculture and small-scale business. The similar levels of material wellbeing achieved is reassuring. Furthermore, consideration of labour market rewards enables comparison with the evidence that underpins the metanarrative that links Britain's 'high wage' economy to industrialization.

Our methodology involves proceeding in stages, first simply adding together the wages of individuals comprising a typical historical family and incorporating some standard assumptions about the labour market engagement of men, women and children and the length 
of the working year. We then make a series of adjustments to assumptions about women's and children's engagement with the labour market, guided at each stage by evidence on the incomes of actual historical families and the working time of women and children. At each stage we report the sensitivity of our findings to the variation in our assumptions as we converge on what we propose as the most historically accurate interpretation.

Section II briefly describes our data sources and the individual earnings' series before combining them into a measure of welfare for a family of five: father, mother and three children, two of whom work. This initial estimate takes an unrealistically optimistic view of the amounts of work done by and available to women and children, 250 days in each year. As a result, family living standards are overestimated. A detailed comparison with surviving historical evidence on the standard of living achieved by some real families reveals the extent of this overshoot in section III. Greater realism requires careful adjustment of our assumptions in the light of information from existing literature and original sources. Thus, section IV considers the participation rates of married women and children and adjusts our series so that it reflects historical conditions rather than a blanket assumption of universal employment. Section V questions the assumption of 250 days worked each year. For men on annual contracts the actual number of days worked does not affect earnings and associated welfare, but an unchanging 250 day working year for other household members is out of line with recent research. Drawing on these new findings we allow the length of the working year to vary over the six centuries studied. Notwithstanding these moves towards greater realism, the relative contributions from married women still appear to be implausibly high. Section VI marshals the scattered evidence on married women's days of work to determine a more credible estimate of their earning power. The resultant series is our best estimate of the standard of living for a typical rural family over six centuries. Section VII makes a final adjustment giving working people some of the benefits of economic growth by incorporating 
the relative expansion of better paid occupations so creating a series representative of all working families. The final section concludes.

Our key contribution is to combine new data on men, women and children's remuneration with source-based estimates of participation rates and days of work per year by age and gender, and gradual changes in the structure of the economy to arrive at estimates of family living standards, 1270-1860. Our measure of material wellbeing over six centuries avoids the standard assumption of family dependence on an adult male worker who works at casual rates for 250 days of the year. Indeed, while trends in families' wellbeing reflect the 'Golden Age' that followed the Black Death and subsequent economic growth, at no time until later industrialisation in the six centuries studied could a respectable standard be attained through men's work alone. The contributions of women and children were crucial to getting the family over the respectability threshold. These secondary earners must be incorporated into accounts of England's escape from Malthusian stagnation into an era of set-back free growth that culminated in the first industrial revolution.

\section{The data series and construction of a measure of household welfare}

Our four wage series combine data collected from hundreds of predominantly primary or printed primary sources, such as manorial, estate or household accounts, from medieval to Victorian times. The sources often refer to the individuals by name and detail the wages they were paid on farms, in households and on construction sites. These are supplemented with comparable information from other sources, such as church wardens' accounts, workhouse records, wage books, surveys of the poor in particular townships, and, for children, schools of industry. Other observations come from secondary sources, such as Arthur Young's tours 
around England in the 1770s and, for boys, Jane Humphries' survey of working-class autobiographies.11

Table 1. Number of observations of individuals in data sources by century.

\begin{tabular}{|l|l|l|l|l|}
\hline Century & Men on annual & $\begin{array}{l}\text { Women on } \\
\text { annual contracts } \\
\text { (single) }\end{array}$ & $\begin{array}{l}\text { Women on } \\
\text { casual contracts } \\
\text { (married) }\end{array}$ & Children \\
\hline $1260-99$ & 550 & 36 & 54 & 73 \\
\hline $1300-99$ & 1835 & 116 & 168 & 342 \\
\hline $1400-99$ & 656 & 456 & 86 & 133 \\
\hline $1500-99$ & 659 & 384 & 365 & 270 \\
\hline $1600-99$ & 1357 & 529 & 601 & 597 \\
\hline $1700-99$ & 1436 & 1707 & 598 & 1245 \\
\hline $1800-50 / 60$ & 239 & 714 & 203 & 3873 \\
\hline Total & 6732 & 3942 & 2075 & 1213 \\
\hline
\end{tabular}

11 Arthur Young, Six Weeks Tour through the Southern Counties of England and Wales (1768); Arthur Young, The Farmer's Tour through the East of England, 4 volumes (1770); Arthur Young, A Six Months Tour through the North of England, 4 volumes (1771); Jane Humphries, Childhood and child labour in the British Industrial Revolution (Cambridge University Press, 2010). 
We have recorded 6,017 observations of women's pay in a variety of occupations, 6,732 of men's pay in agricultural occupations and 3,873 observations of children's pay. Care was taken to exclude skilled occupations and London wages. Geographical location was noted and controlled for in analysis. For children the data is heterogeneous. $68.4 \%$ of our observations are for boys, reflecting the difficulty of identifying girls and their associated occupations in these sources. Age is known for $30.6 \%$ of the sample and indicated for a further $15 \%$. For the remainder we ascribe age 11 or age 14 as implied by the source or type of work. The children worked in a variety of occupations: broadly classified as agriculture, mining, cottage industry, manufacturing, service, distribution, construction, and other. Agriculture predominated throughout, but service jobs were also common. Girls were often occupied in cottage industry whereas mining was generally the preserve of boys. Most observations came from the South East of England, but other regions were represented.

We recorded occupations, wages and the timetable for remuneration (usually daily, weekly, annual) and, for children, the characteristics mentioned above. We also collected information on payments in kind, specifically whether the individual was boarded, lodged or clothed. We initially work on the assumption that for those on day rates 250 days were worked per year throughout the period but revisit this assumption later.

Additionally, we need to value in kind payments. Robert Allen's respectability consumption basket involves a diet that exceeds subsistence calorically and in terms of protein as well as a clothing, heating and housing allowance as detailed in table 2. His website provides the changing costs of this standard basket over the six centuries of our study. We refer to this source to impute values for board, lodging and clothing but, for children, recalibrated 
according to their needs, assumed as one half of an Allen basket.12 Finally, because the standard of living refers to any random day in the year, we have to allow for the receipt of in kinds by individuals who are boarded and lodged even on days when they are not working. Thus, for workers on annual contracts we add to their yearly monetary pay the daily cost of a respectability basket multiplied by 365 days to represent the annual value of the in-kinds that they enjoy. Once we have established the annual income from work we divide by the annual cost of an Allen basket, to arrive at a measure of the standard of living, our 'welfare ratio'. It represents the number of respectability baskets a person can consume per day from his/her waged work. For a day worker the day rate is multiplied by 250 days, the standard assumption about the length of the working year, and then divided by the annual cost of the Allen basket, to arrive at the relevant ratio.

Table 2. Components of the Allen basket

12 Again this enables comparability with other series on men and women's wages, see Humphries and Weisdorf 'Wages of women', 'Unreal wages?', and is consistent with Allen's own suggestion that a family of husband, wife and two or three children would require three baskets, see Allen, British Industrial Revolution. Use of an alternative measure when valuing children's perquisites, the cost of 1500kcal of energy from wheat, yields essentially the same results, see Horrell and Humphries, 'Children's work'. The respectability basket might be overgenerous, families could economise by eating oats rather than bread and cutting down their consumption of meat, cheese and beer, and still achieve 2,100 calories per person (R. C. Allen, 'The high wage economy and the industrial revolution: a restatement', Economic History Review, 68 (2015) t.2). Even so, at only 2,500 calories for an adult male if wheaten bread was eaten the respectability basket remains none too generous for a working man. 


\begin{tabular}{|l|l|l|}
\hline & \multicolumn{2}{l|}{ Respectability basket } \\
\hline Good & $\begin{array}{l}\text { Quantities per } \\
\text { year }\end{array}$ & Calories per day \\
\hline Oats & $234 \mathrm{~kg}$ & 1571 \\
\hline Bread & $52 \mathrm{~L}$ & 370 \\
\hline Beans/ peas & $26 \mathrm{~kg}$ & 178 \\
\hline Meat & $5.2 \mathrm{~kg}$ & 104 \\
\hline Butter & $5.2 \mathrm{~kg}$ & 54 \\
\hline Cheese & $52 \mathrm{each}$ & 11 \\
\hline Eggs & $182 \mathrm{~L}$ & 212 \\
\hline Beer & $2.6 \mathrm{~kg}$ & \\
\hline Soap & $5 \mathrm{~m}$ & \\
\hline Linen & $2.6 \mathrm{~kg}$ & \\
\hline Candles & $2.6 \mathrm{~L}$ & \\
\hline Lamp oil & $5.0 \mathrm{M}$ BTU & \\
\hline Fuel & 500 & \\
\hline Rent & & \\
\hline Total calories & & \\
\hline Source: Allen & Brince & \\
\hline
\end{tabular}

Source: Allen, British Industrial Revolution, t.2.1.

The children's data, while detailed, is also heterogeneous in terms of source, occupation, region, gender, age and payment contract. Raw averages, even aggregated over ten-year periods, would be characterised by spurious variation caused by the shifting composition of the sample. We use regression analysis to control for heterogeneity in the sources and structure of the sample and so isolate the variation over time.13 The coefficients derived from the regression analysis allow us to identify the experience of children of different genders and

${ }^{13}$ For details of the method and tabulation of the results see Horrell and Humphries, 'Children's work'. 
in different occupations and payment schedules. Our baseline child is a boy working in agriculture on day pay in the south east of England. Figure 1 graphs the welfare ratios of various individual family members according to our estimates of their wages and assumptions about working time, and for children controlling for heterogeneity in the underlying sources. For comparison it also shows the welfare ratios for a male farm worker earning casual wages and working 250 days in the year.14

Welfare ratio of individual family members based on earnings estimates.

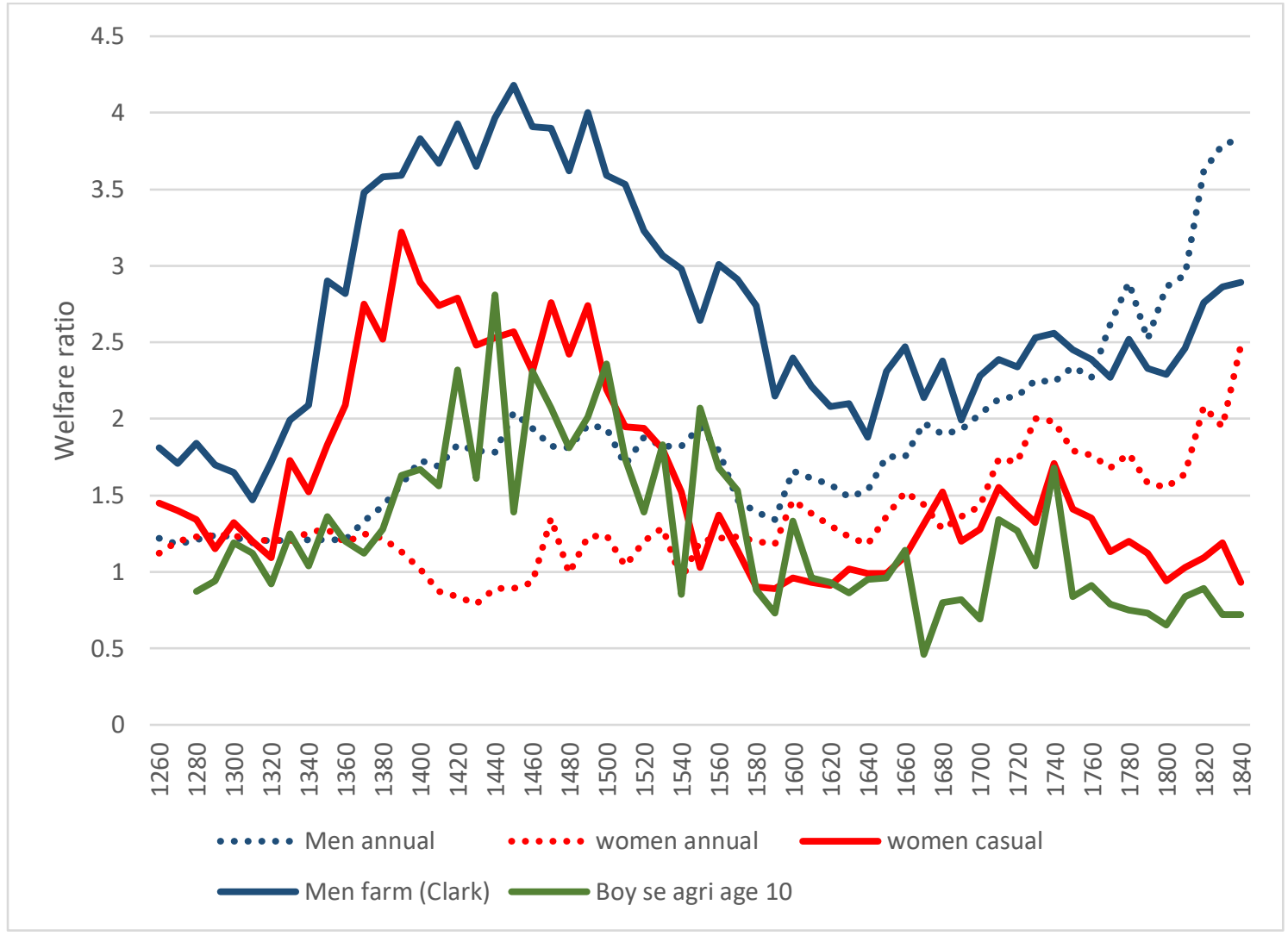

Sources: see text and Clark, 'Long march of history'.

${ }_{14}$ Clark, 'Long march of history.'. 
Recent grand narratives have relied on trends in male casual workers' wages for their underlying evidence. Our graph reflects some of these same trends. There is a huge boom in the welfare ratios of casual workers assumed to be working 250 days in the year in the late medieval period, after the demographic catastrophe of the Black Death and the subsequent labour shortage. Clark's farm labourers illustrate this bonanza but our evidence suggests that women and children too working casually, capitalised on the labour scarcity. But Tudor times saw these gains partially eroded. There was a short-lived improvement in the first half of the eighteenth century, contemporaneous with the 'industrious revolution', but relatively low levels of pay persisted through industrialisation. Our introduction of the experience of workers on annual contracts adds a new perspective. Their situation was initially less rosy. Female workers on annual contracts have been identified as being predominantly single women, more able to accommodate residence with an employer than women with children and domestic responsibilities, while service was a suitable vehicle for controlling what the authorities feared would be disruptive independence. Conversely those in casual employment were typically married women and frequently described as such in the sources.15 Young single women appear not to have shared in the 'Golden Age' of booming wages experienced by day workers, casting doubt on the standard account of the origins and persistence of a distinctive North European Marriage Pattern, with its emphasis on their ability and willingness to delay or forego marriage.16 Male workers on annual contracts, saw delayed and muted gains relative to the estimates for their day-working fellows suggesting that the

\footnotetext{
15 For a detailed discussion see Humphries and Weisdorf, 'Women's wages'. 16 Tine de Moor and Jan Luiten van Zanden, 'Girl Power: The European Marriage Pattern and Labour Markets in the North Sea Region in the Late Medieval and Early Modern Period,'
} Economic History Review, 63 (2010). 
working year in this period was shorter than the commonly-assumed 250 days.17 The gap between annual and day pay narrowed in the sixteenth and seventeenth centuries, implying a lengthening working year with the early advent of industriousness eliciting economic growth. Industrialisation involved new dynamics. Men gained at the expense of women and children and an annual contract was to be prized.

\section{Family remuneration and welfare}

To move from individual to family welfare we need to know the size and structure of the standard family. In line with Laslett's and Wall's observations of an unchanging household size of 4.75 people in England from the sixteenth to the nineteenth century, 18 we define our family as comprising five people, husband, wife and three children, aged three (representing 0-4 age group), seven (5-9 years), and twelve (10-14 years) years old. We then ask what it cost to maintain such a family at the respectable standard. If adults require a whole

17 Assuming arbitrage in the labour market, the length of the working year is predicted from the number of days work at the daily rate that would have been required to achieve the annual stipend, see Humphries and Weisdorf, 'Unreal wages'5-6.

18 Peter Laslett, 'Mean household size in England since the sixteenth century', in Peter Laslett and Richard Wall (eds.), Households and family in past time (Cambridge University Press, 1972); Richard Wall, 'Mean household size in England from published sources', in Laslett and Wall (eds.), Households and family. Laslett, p.76 table 1.6 finds mean household size to stand at 4.75 from 1574-1821 in 100 English communities, and Wall, p.192, table 5.2, using printed sources for 409 settlements finds household size to range from 4.60 to 4.92 over the years 1695-1801. 
respectability basket and a child just half, our family will need 3.5 Allen baskets, our new family cost of living index, to achieve a family welfare ratio of one.

We assume that the husband worked full-time in an unskilledjob, corresponding to the mass of working families, and was able to earn the same as a man on an annual contract. We represent his wife's remuneration by that of women on unskilled day rates since, as noted above, annual service was usually the preserve of young single women, while married women had access to the casual labour market.19 Initially, we assume our woman had a standard of living per day based on working for 250 days annually.20 For children we use the coefficients retrieved from the regression analysis to construct the trend in remuneration for a boy aged twelve working in agriculture and a girl aged seven working in cottage industry, both in the south east of England. The three-year old child is assumed dependent within the household.21

Our family members all work in unskilled, rural occupations. Their situation is likely to understate the position of more fortunate groups with access to jobs in more dynamic sectors of the economy such as domestic manufacturing, mining and maybe even transport and distribution. However, it will present an optimistic view compared with those less-fortunate households headed by a widow or with an incapacitated father, household types that may have represented one fifth of the population.22 The optimism embedded in our initial account

19 Humphries and Weisdorf, 'Women's wages'.

20 That is, day wage $\mathrm{x} 250 / 365$ days.

21 See Horrell and Humphries, 'Children's wages', for a full discussion of the trend analysis. 22 Estimates range from over ten percent in the late eighteenth and early nineteenth centuries (see Jane Humphries, 'Female-headed households in early industrial Britain: the vanguard of the proletariat', Labour History Review, 63 (1998)), 15 percent in nineteen English 
of family standards largely derives from the underlying assumption that women and children would and could all engage fully in paid work. We adjust this assumption towards greater historical realism below.

We construct our family welfare measure by summing the remuneration of the husband, his wife and the two working children and then dividing the resulting family income by the cost of a family Allen basket. Figure 2 shows the evolution of the family welfare ratio relative to a respectability benchmark (ratio=1). It represents the number of family respectability baskets that the collective income could afford over time. For context we also show what proportion of a family basket a man alone could purchase.

Figure 2. Family welfare afforded by male annual earnings alone and whole family working. (250 days of work per year at casual rates assumed for women and children, measured relative to Allen's respectability basket x 3.5).

communities 1599-1811 (see Peter Laslett, 'Parental deprivation in the past: a note on the history of orphans in England', Local Population Studies, 13 (1974)) to 19.1 percent in Bristol in 1690s (see J. R. Holman, 'Orphans in pre-industrial towns: the case of Bristol', Local Population Studies, 15 (1975)) 


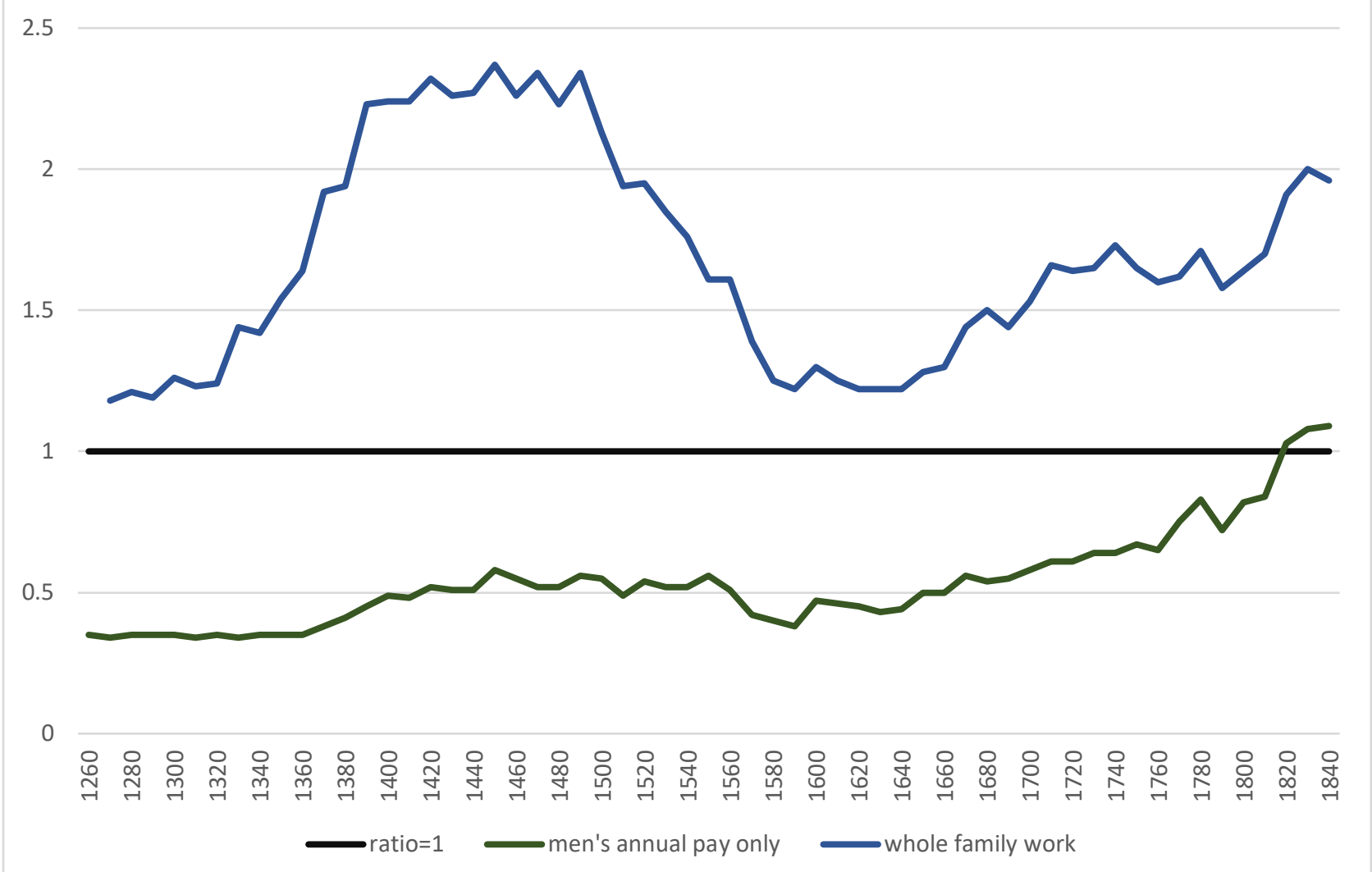

Sources: see text and figure 1.

Men's pay over the year alone was clearly insufficient to sustain their families until the early decades of the nineteenth century. Other family members needed to work if the family was to manage a decent standard of living that afforded them the basics with sufficient nutrition to undertake laborious work.23 Adding the contributions of other family members dramatically improves welfare. Although in many decades the position of the family remained one of only borderline respectability, the mid-fourteenth to mid-sixteenth centuries afforded

23 This finding is demonstrated in detail in Sara Horrell, Jane Humphries and Jacob Weisdorf, 'Working for a living? Women's and children's labour inputs in England, 1260-1850', University of Oxford working paper (2019). 
unprecedented prosperity. On this measure the rural family was able to buy the goods needed to secure a comfortable standard twice over.

\section{Assessing the plausibility of this initial measure of household welfare.}

We have highlighted the optimistic bias of this initial pass at the estimation of family living standards through our assumptions that all family member's worked and that women and children worked full-time for 250 days per year. We can demonstrate the extent of this optimism by comparing our results with welfare ratios that we can construct for some wellknown and 'respectable' families who appear in the early modern literature (table 3 and figure 3). The comfortable position of Eden's Ealing gardener has been much fêted, even so, his welfare ratio of 1.32 lay somewhat below the position of the average unskilled labouring household in 1790 suggested here.24 Similarly, the prosperous and well-resourced early eighteenth-century Latham family was unable to match these levels.25 Muldrew's hypothetical work-rich households did outperform our labouring family in the mid-sixteenth century but appear more in line by the seventeenth.26 Gregory King's late-seventeenth century freeholders and artisans could, on his estimate, support a rather more luxurious

24 Sir Frederic Morton Eden (ed. A. G. L. Rogers) The State of the Poor: a history of the labouring classes in England, with Parochial reports, 3 volumes (1928)

25 John Styles, Dress of the People, everyday fashion in eighteenth century England (Yale University Press, 2007) pp.229 ff.

${ }_{26}$ Craig Muldrew, Food, energy and the creation of industriousness (Cambridge University Press, 2011) p.217, p.257. 
lifestyle than our working household, but his labourers were quite closely matched.27 A little beyond the period we are considering, Le Play's mid-nineteenth century skilled cutler's family could just reach the same standard of living from work as our labouring family, although the ironworker's fared somewhat better.28 These early industrial estimates suggest that our welfare measure overstates the resources that would be available to a representative family.

Table 3. Welfare ratios for some actual and constructed families, early modern and industrial periods

\begin{tabular}{|c|c|c|c|c|c|c|c|}
\hline $\begin{array}{l}\text { Year } \\
\text { (source, see } \\
\text { notes) }\end{array}$ & H'hold type & $\begin{array}{l}\text { Annua } \\
1 \\
\text { h'hold } \\
\text { incom } \\
\text { e (£) }\end{array}$ & $\begin{array}{l}\text { Wife's } \\
\text { contributio } \\
n(£)\end{array}$ & $\begin{array}{l}\text { Children's } \\
\text { contributio } \\
\mathrm{n}(\mathfrak{})\end{array}$ & $\begin{array}{l}\text { Adult } \\
\text { equiv } \\
\text { h'hol } \\
\text { d size }\end{array}$ & $\begin{array}{l}\text { Cost one } \\
\text { respectabilit } \\
\text { y basket per } \\
\text { day (d) }\end{array}$ & $\begin{array}{l}\text { Family } \\
\text { welfar } \\
\text { e ratio }\end{array}$ \\
\hline 15681 & \multirow{4}{*}{$\begin{array}{l}\text { Constructed } \\
\text { : } \\
\text { agricultural } \\
\text { worker and } \\
\text { spinners }\end{array}$} & 17.7 & 5.2 & 2 & 3.5 & 1.46 & 2.28 \\
\hline $1597_{1}$ & & 19.1 & 5.2 & 2 & 3.5 & 2.39 & 1.50 \\
\hline 16251 & & 22.95 & 6.05 & 2 & 3.5 & 2.83 & 1.46 \\
\hline $\begin{array}{l}1690 / 50 \\
1\end{array}$ & & 28.55 & 9.25 & 3 & 3.5 & 3.2 & 1.68 \\
\hline $\begin{array}{l}1760 / 40 \\
1\end{array}$ & & 33.3 & 11.5 & 4 & 3.5 & 3.05 & 2.05 \\
\hline 16882 & $\begin{array}{l}\text { Labourer/ } \\
\text { servant }\end{array}$ & 20 & & & 2.5 & 2.97 & 1.77 \\
\hline 16882 & $\begin{array}{l}\text { Lesser } \\
\text { freeholder }\end{array}$ & 40 & & & 4 & 2.97 & 2.21 \\
\hline 16882 & Artisan & 40 & & & 3.5 & 2.97 & 2.53 \\
\hline 16983 & $\begin{array}{l}\text { Advisory } \\
\text { budget }\end{array}$ & 9.375 & 3.125 & 0 & 3.5 & 3.125 & 0.56 \\
\hline 1724- & Latham & 30 & $?$ & $?$ & 5 & 3.2 & 1.23 \\
\hline
\end{tabular}

27 Calculated from the discussion in Richard Stone, 'Some seventeenth century econometrics: consumers' behaviour', Revue europeenne des sciences sociales, XXVI, 81 (1988).

28 Frederic Le Play, Les Ouvriers Europeens, vol. 3 (Paris, 1857). 


\begin{tabular}{|c|c|c|c|c|c|c|}
\hline 674 & $\begin{array}{l}\text { family: } \\
\text { farming and } \\
\text { spinning }\end{array}$ & & & & & \\
\hline 17905 & $\begin{array}{l}\text { Ealing } \\
\text { gardener }\end{array}$ & 38.6 & 1 & 4 & 4.76 & 1.32 \\
\hline 18506 & Ironworker & 70.61 & 5.58 & 4 & 5.21 & 2.40 \\
\hline 18546 & Cutler & 44.82 & 2.15 & 3.5 & 5.21 & 1.62 \\
\hline
\end{tabular}

Sources and notes: 1. Muldrew, Food, p.257 table 5.19, p.217 table 5.4, constructed households: man in agriculture, woman spinning and in agriculture, children work, family size assumed 2 adults, 3 children $=3.5$. 2. Stone, 'Consumers' behaviour', from Gregory King's notebook, table 6 . Income per family, labourers and servants 3 people per household, lesser freeholders 6 people per household, artisans 5 people per household. 3. Richard Dunning, Bread for the poor: or, a method showing how the poor may be maintained and duly provided for, in a far more plentiful and yet cheaper manner ... (Exeter, 1698), advisory budget. 4. Styles Dress pp.229ff. Latham family, income estimated about £30 per annum, household comprises man, woman, 6 daughters, 3 left home, one son, daughters and wife spin; 5. Jane Humphries, 'The lure of aggregates and the pitfalls of the patriarchal perspective: a critique of the high wage economy interpretation of the British industrial revolution', Economic History Review, 66 (2013) from Eden, State of the Poor, Ealing gardener, wife and four young children. 6. Le Play, Ouvriers, ironworker, Derbyshire, four children aged 4 to 11 years old, cutler, Sheffield, wife makes 'pop', three children aged 5 to 10 years old.

We can conduct a similar, but necessarily more speculative, exercise for the medieval period. A number of scholars have made estimates of the income of the peasant household for the 
thirteenth to the fifteenth centuries. 29 Conducted for various sizes of landholding, this essentially involves careful inference about fallow, rotations, crops grown, yields, livestock kept and the resulting produce. For different sizes of land holding the marketable surplus after the family's direct consumption needs have been satisfied can be valued. From this, tithes, rents, milling tolls, repair of equipment and costs of labour employed are deducted. We work with the surplus cash available for expenditure and an estimate of the cost of the family's self-produced food based on either the respectability basket or the less generous appositely-named 'bare bones' basket as appropriate.30 Family welfare ratios for different categories of peasant household can then be computed (table 4).

Table 4. Family welfare ratios for medieval peasant households (based on a typical family size of man, woman and three, usually dependent, children. The man is assumed to devote his time to the smallholding and/or to paid labour. Valued relative to the cost of the respectability basket).

\begin{tabular}{|l|l|l|l|l|l|}
\hline Year & Landholding & $\begin{array}{l}\text { Consumption } \\
\text { basket }\end{array}$ & $\begin{array}{l}\text { Cash } \\
\text { surplus }\end{array}$ & $\begin{array}{l}\text { Household } \\
\text { members' } \\
\text { work }\end{array}$ & $\begin{array}{l}\text { Family } \\
\text { welfare } \\
\text { ratio }\end{array}$ \\
\hline
\end{tabular}

${ }_{29}$ Christopher Dyer, Standards of Living in the Later Middle Ages. Social change in England 1200-1520 (Cambridge University Press, 1989); Harry Kitsikopoulos, ‘Standards of living and capital formation in pre-Plague England: a peasant budget model', Economic History Review, 53 (2000); John Hatcher, 'Seven centuries of unreal wages' in John Hatcher and Judy Z. Stephenson (eds.) Seven centuries of unreal wages: the unreliable data, sources and methods that have been used for measuring standards of living in the past (Palgrave Studies in Economic History, 2019).

30 The bare bones basket composition is documented in Broadberry et al, British Economic Growth, p.333. 


\begin{tabular}{|c|c|c|c|c|c|}
\hline $1299_{1}$ & & & & & \\
\hline \multirow{5}{*}{$\begin{array}{l}\text { Actual } \\
\text { accounts: } \\
\text { Cleeve Manor, } \\
\text { Worcs. }\end{array}$} & $\begin{array}{l}30 \text { acres } \\
\text { Yardlander }\end{array}$ & respectability & $£ 1$ & $\begin{array}{l}\text { Wife helped, } \\
\text { brewed and } \\
\text { spun }\end{array}$ & 1.36 \\
\hline & $\begin{array}{l}15 \text { acres } \\
\text { Half- } \\
\text { yardlander }\end{array}$ & barebones & $4 \mathrm{~s}$ & $\begin{array}{l}\text { Earnings of } \\
\text { women and } \\
\text { children } \\
\text { would be } \\
\text { important } \\
\end{array}$ & 0.53 \\
\hline & $\begin{array}{l}12 \text { acres } \\
\text { Cotlander }\end{array}$ & barebones & - & & 0.46 \\
\hline & $\begin{array}{l}3 \text { acres } \\
\text { Smallholder }\end{array}$ & barebones & & $\begin{array}{l}\text { Needs to } \\
\text { work } 130 \\
\text { days at } 1.5 \mathrm{~d} \\
\text { for bare } \\
\text { bones. } \\
\text { Earnings } \\
\text { women and } \\
\text { children } \\
\text { crucial } \\
\end{array}$ & 0.46 \\
\hline & Average* & & & & 0.913 \\
\hline \multicolumn{6}{|l|}{$1300-1350$} \\
\hline $\begin{array}{l}\text { Detailed } \\
\text { reconstruction }\end{array}$ & $\begin{array}{l}18 \text { acres } \\
\text { Half virgate } \\
+ \text { meadow }\end{array}$ & bare bones & $7 \mathrm{~s} 7 \mathrm{~d}$ & $\begin{array}{l}\text { Son working } \\
\text { age. Land } \\
\text { requires } \\
443.5 \text { days, } \\
\text { from man, } \\
\text { woman and } \\
\text { son. Each } \\
\text { also do } 80 \\
\text { days outside } \\
\text { employment }\end{array}$ & 0.54 \\
\hline \multicolumn{6}{|l|}{$1348-9_{3}$} \\
\hline \multirow{5}{*}{$\begin{array}{l}\text { Reconstruction } \\
\text { with } \\
\text { assumptions, } \\
\text { covering } 90 \% \\
\text { rural } \\
\text { population } \\
\text { (75\% whole } \\
\text { population). } \\
\text { Only male } \\
\text { work } \\
\text { considered, } \\
\text { own land } \\
\text { requires } 13 \\
\text { days per acre }\end{array}$} & Landless & & & $\begin{array}{l}150 \text { days } \\
\text { paid work } \\
@ 1.5 \mathrm{~d}\end{array}$ & 0.32 \\
\hline & 5 acres & & & $\begin{array}{l}140 \text { days } \\
\text { paid @ } 1.5 \mathrm{~d}\end{array}$ & 0.43 \\
\hline & 10 acres & & & $\begin{array}{l}100 \text { days } \\
\text { paid @ } 1.5 \mathrm{~d}\end{array}$ & 0.49 \\
\hline & 18-20 acres & & & $\begin{array}{l}\text { All man's } \\
\text { labour on } \\
\text { farm }\end{array}$ & 0.87 \\
\hline & $36-40$ acres & & & Hires labour & 2.01 \\
\hline \multicolumn{6}{|l|}{$1450-793$} \\
\hline $\begin{array}{l}\text { Reconstruction } \\
\text { with }\end{array}$ & Landless & & & $\begin{array}{l}30 \text { days paid } \\
\text { @ 4d, } 120\end{array}$ & 0.54 \\
\hline
\end{tabular}




\begin{tabular}{|c|c|c|c|c|c|}
\hline \multirow{5}{*}{$\begin{array}{l}\text { assumptions, } \\
\text { see above }\end{array}$} & & & & @ 2.5d & \\
\hline & 5 acres & & & $\begin{array}{l}20 \text { days @ } \\
4 \mathrm{~d}, \\
120 @ 2.5 \mathrm{~d}\end{array}$ & 0.61 \\
\hline & 10 acres & & & $\begin{array}{l}\text { 15 days @ } \\
4 \mathrm{~d}, 85 @ 2.5 \mathrm{~d}\end{array}$ & 0.64 \\
\hline & 18-20 acres & & & $\begin{array}{l}\text { Own land } \\
\text { requires } \\
\text { man's labour }\end{array}$ & 0.83 \\
\hline & $36-40$ acres & & & Hires labour & 1.52 \\
\hline \multicolumn{6}{|l|}{14751} \\
\hline \multirow[t]{4}{*}{$\begin{array}{l}\text { Actual } \\
\text { accounts: } \\
\text { Cleeve Manor, } \\
\text { Worcs. }\end{array}$} & Yardlander & Respectability & $£ 2$ & $\begin{array}{l}\text { Household } \\
\text { size reduced: } \\
2 \text { adults and } \\
2 \text { children }\end{array}$ & 1.71 \\
\hline & $\begin{array}{l}\text { Half- } \\
\text { yardlander }\end{array}$ & $\begin{array}{l}\text { Between } \\
\text { respectability } \\
\text { and bare } \\
\text { bones }\end{array}$ & $15 \mathrm{~s} 4 \mathrm{~d}$ & & 1.01 \\
\hline & Cottager & Barebones & $\begin{array}{l}\text { Works } 135 \\
\text { days, } \\
\text { surplus } \\
\text { after } \\
\text { barebones } \\
\text { satisfied } 60 \\
\text { days@ } 4 \text { d } \\
\end{array}$ & $\begin{array}{l}\text { Wife } \\
\text { contributes } \\
\text { to earnings }\end{array}$ & 0.84 \\
\hline & Average $* *$ & & & & 1.20 \\
\hline
\end{tabular}

Sources: 1. Dyer, Standards of living, pp.109-18, 148-50 2. Kitsikopoulos, 'Standards of living'. 3. Hatcher, 'Seven centuries'.

Notes: * average weighted by proportions of landholdings from 1279-80 Hundred Rolls (Dyer, Standards of living, pp.118-19). ** average based on share type of landholding represents of 53 tenants in Cleeve rental record.

Figure 3. Comparison of household observations and calculations for medieval peasant families with the aggregated family wage data. 


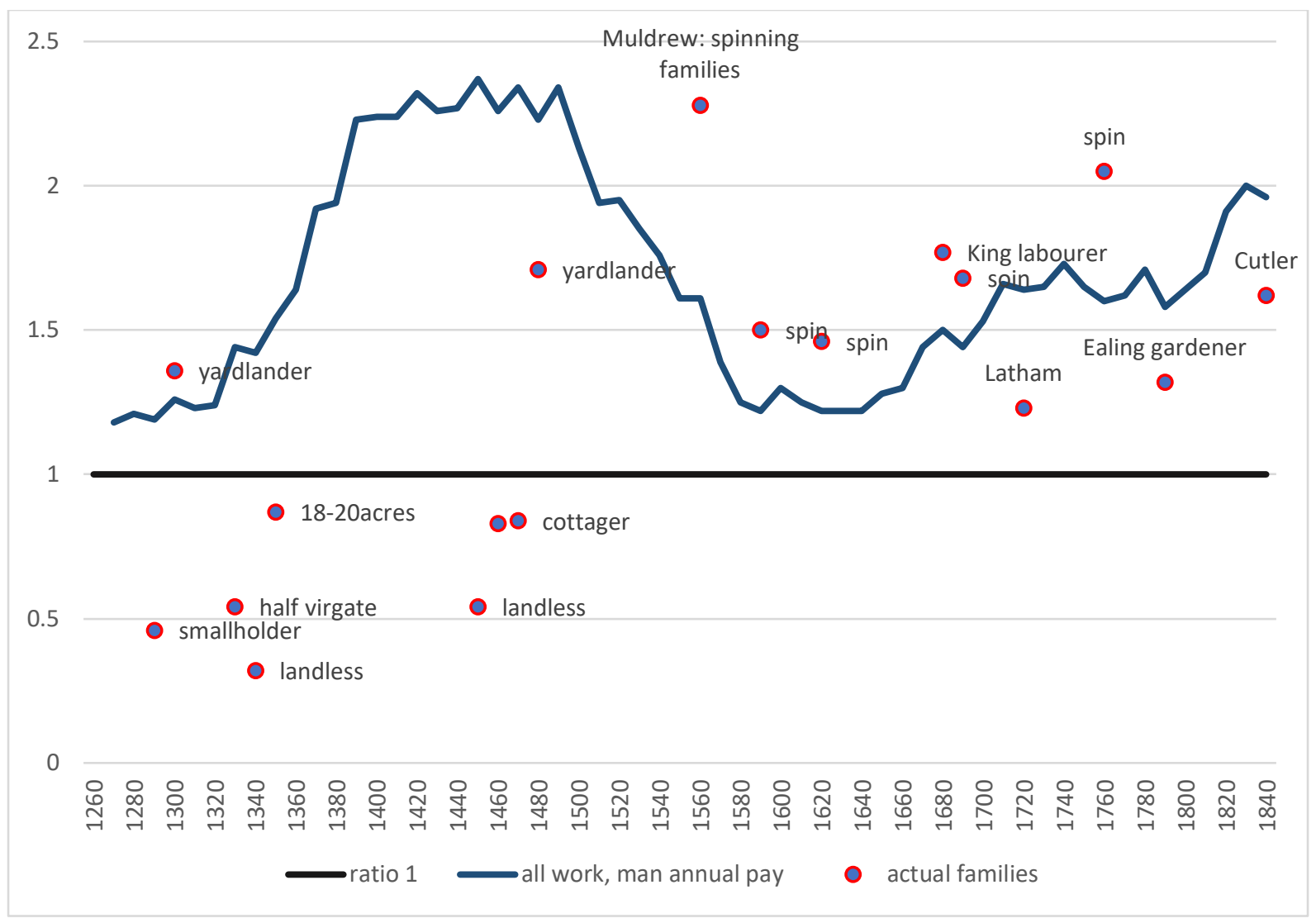

The comparisons suggest that our estimates of welfare overshoot the historical reality (figure 3). The explanation lies in our dubious assumption of universal participation in paid work for 250 days of the year by women and children, an assumption that we noted initially was likely excessive (figure 3). The medieval peasant households differ in their consideration of the inputs of women and children but, where this is included, a family welfare ratio of just 0.54 is reached in 1300-1350.31 This is a family with half a virgate of land, a holding of the size or greater than some 46 per cent of pre-plague agriculturalists. Indeed, the vast majority of the rural population were living on inadequate landholdings, with few able to achieve the respectable consumption basket through their work.32

\footnotetext{
31 Kitsikopoulos 'Standards of living'.

32 Hatcher, 'Seven centuries', p.18 and estimates from Dyer, Standards of living, above.
} 
The years following the Black Death provided some improvement and the estimates for specific households presented here probably understate the gain. The expansion of opportunities for women's work are not incorporated and the constructed estimates neglect some of the technological improvement in agricultural methods, the potential to expand pastoral husbandry, and the possibility of employing servants rather than day labourers on the land. But even the gains indicated suggest that more families could achieve a respectable level of consumption. The proportion of landless and near landless decreased from maybe two thirds pre-1349 to less than one half in the later fifteenth century and a larger proportion of those with land had holdings sufficient for subsistence .33 Gains are undeniable, but they do not elevate families to the heady heights implied by measure of earnings for this period. Of course, some of the shortfall experienced by the real families extracted from the historical record results from fewer than 250 days being worked in the year. As both Dyer and Hatcher have pointed out, it is unlikely that this amount of work was actually on offer and it is even more unlikely that people would be acquiring additional land to farm themselves, as undoubtedly occurred, if the gains from so doing were less than could be achieved through paid employment. The estimates for the peasant households suggest something close to subsistence prior to the Black Death with some subsequent improvement, although many landowning families remained unable to access a consumption bundle that delivered respectability.

Overall, the welfare ratios deduced from the income and structure of actual families rarely matched up to the level of material welfare implied from our wage aggregation. The assumption of intensive labour market engagement by all family members clearly imparts an optimistic bias. In the following sections we make appropriate adjustments to participation rates and to the number of days worked by women and children to refine our estimates.

33 Hatcher, 'Seven centuries'. 


\section{Participation rates of women and children.}

An optimistic view of the remuneration of our family members (man annual, women casual, children casual) has been presented above. Moreover, this family is lucky, both parents are present and able to work, and the children also have opportunities to contribute to household income. For many families employment opportunities were not so easy to come by, work might have been intermittent or unavailable, while family members themselves may have been incapacitated and unable to contribute. A more realistic picture of family living standards requires taking these diverse experiences into account. We retain the assumption that the adult male is able to find full time work, but now review the evidence on actual historical participation rates of children and women.

\section{Children's participation rates in long-term perspective.}

There is relatively little information on children's participation rates for much of the period we are considering. We utilise information available for the early modern period from Surveys of the Poor, household budgets and censuses to construct an estimate of the proportion of children working (table 5, figure 4). Rates are assumed to be 75 percent for our twelve-year old boy and 50 percent for our seven-year old girl in the earlier centuries. There was relatively little legislation affecting children's work throughout the period. Compulsory education was not introduced in Britain until 1870. The main workplace legislation was the Factory Act 1833 and the Coal Mines Regulation Act 1842. The former applied to cotton and woollen manufactories, banned the employment of children under nine years of age, stipulated a maximum eight hour day for nine to thirteen year-olds and twelve hours for thirteen to eighteen year- olds, and required education for two hours per day for under 
thirteen year- olds. The latter prohibited all women and girls and boys under ten from working underground. The legislation acted to restrict children's employment in these occupations but probably crowded them into unregulated sectors. 34

Table 5. Children's participation rates.

\begin{tabular}{|c|c|c|c|c|c|c|}
\hline Year & Ages & & & Ages & & \\
\hline & Boys & All & Girls & Boys & All & Girls \\
\hline $\begin{array}{l}1570 \\
\text { Norwich }\end{array}$ & & $\begin{array}{l}36.3-49.5 \\
(380)\end{array}$ & & & $\begin{array}{l}73.5-86.7 \\
(181)\end{array}$ & \\
\hline $\begin{array}{l}1597 \\
\text { Ipswich }\end{array}$ & & $\begin{array}{l}25.8-36.4 \\
(66)\end{array}$ & & & $\begin{array}{l}56.3-70.3 \\
(64)\end{array}$ & \\
\hline $\begin{array}{l}1625 \\
\text { Salisbury }\end{array}$ & & $\begin{array}{l}18.5-29.6 \\
(27)\end{array}$ & & & $\begin{array}{l}66.7-73.3 \\
(30)\end{array}$ & \\
\hline \begin{tabular}{|l|l}
1790 \\
Dorset
\end{tabular} & $\begin{array}{l}9.6 \\
(83)\end{array}$ & & $\begin{array}{l}11.0 \\
(82)\end{array}$ & $\begin{array}{l}66.7 \\
(66) \\
\end{array}$ & & $\begin{array}{l}69.6 \\
(79) \\
\end{array}$ \\
\hline $1787-96$ & & 10.5 & & & 54.1 & \\
\hline 1830-39 & & 9.2 & & & 70.4 & \\
\hline $1840-54$ & & 6.9 & & & 41.6 & \\
\hline 1851 & 2.0 & & 1.4 & 36.6 & & 19.9 \\
\hline 1861 & 2.0 & & 1.1 & 36.9 & & 20.2 \\
\hline
\end{tabular}

Notes: Ranges for the early participation rates are for those recorded as working full-time compared with those working and simultaneously in school. In a number of cases 'skole to

${ }_{34}$ Clark Nardinelli, Child labor and the Industrial Revolution (Indiana University Press, 1990); Sara Horrell and Jane Humphries, "'The exploitation of little children": child labor and the family economy in the industrial revolution', Explorations in Economic History, 32 (1995); Peter Kirby, Child workers and industrial health in Britain 1780-1850 (Boydell and Brewer, Suffolk, 2013). 
spyn' is recorded which would be akin to on-the-job training and hence should maybe be considered as work.

(sample sizes, except national Census, in parentheses)

Sources:

1570 J. F. Pound, “An Elizabethan census of the Poor", University of Birmingham Historical Journal, vol III, no. 2 (1962). Also Census of the Poor Norwich 1570-1580 www.welbank.net/norwich/1570/1570data.html; 1597 John Webb, ed., Poor relief in Elizabethan Ipswich, Ipswich, Suffolk Records Society, vol.IX. 'A census of the poor 1597', (1966); 1635 Paul Slack, ed., 'Poverty in Early Stuart Salisbury', Wiltshire Record Society, XXXI (1975). Devizes. St Edmund's and St. Thomases' parishes, pp.75-80; 1790 Census of Corfe Castle, Dorset from Osamu Saito, 'Who worked when? Lifetime profiles of labourforce participation in Cardington and Corfe Castle in the late-eighteenth and mid-nineteenth centuries', Local Population Studies, 22 (1979); 1787-1854 Horrell and Humphries, 'Exploitation', t. 4, participation rates by age and father's occupation. Aggregated using male employment weights from Sara Horrell, 'Home demand and British industrialisation', Journal of Economic History, 56 (1996), n.38, p.580. Children from families with two parents, participation assumed where any earnings or an occupation was recorded; 1851-1861 Censuses of England and Wales, Michael Lavalette, 'The changing form of child labour circa 1880-1918. The growth of 'out of school work', in Michael Lavalette (ed) A Thing of the Past? Child labour in Britain in the nineteenth and twentieth centuries (University of Liverpool Press, 1999), t. 5.1 p.124.

Figure 4. Constructed participation rates for children and for married women. 


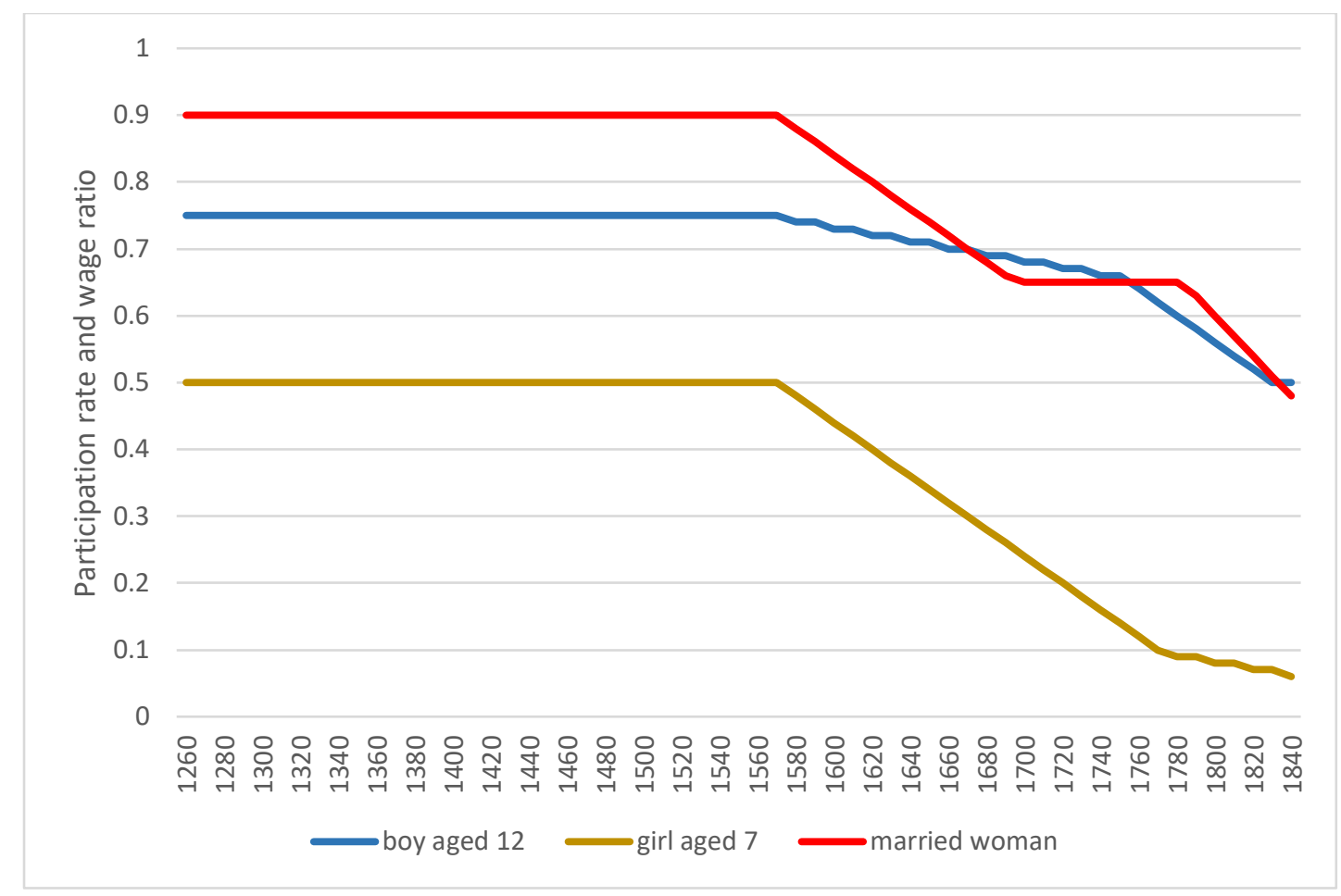

Sources: see text

Women's participation rates and income contribution

We know a little more about women's participation rates and contributions to household incomes from a variety of local censuses and, by 1851 , the national census. . Women's participation can also be estimated from the writings of Sir Frederic Morton Eden (1795), Arthur Young (1768-1770) and Daniel Defoe (1724-6) (table 6).35 Most of the sources from which we can extract women's participation rates are straightforward, but our computation of

35 Eden, State of the poor; Young, Six weeks tour, The farmer's tour, Six months tour; Daniel Defoe, (1724-6) A Tour thro' the Whole Island of Great Britain, first edition, reprinted 1928, J. M. Dent and Sons Ltd, London, volumes 1 and 2, with an introduction by G.D.H. Cole. 
participation from the three accounts above requires further explanation. 36 In brief, Eden in his investigation of the 'State of the Poor' reports returns from 156 parishes which explicitly mention the availability of employment for women. For each county we create an index of the sector of employment (agriculture, textile, manufacture, no employment) and the proportion of parishes in the county reporting employment in the sector. Thus 5 parish observations where one has agricultural work, three have textile work and one has no work would convert to 20 percent, 60 percent and 0 percent within the county leading to 80 percent employment. We then weigh each county's contribution to a national figure by its proportion of the total population of England and Wales and sum. But Eden's observations are largely from rural areas so we adjust these totals for the relevant proportion of urban to rural population in each county. 37 We assume 50 percent of the women in urban areas have opportunities to work in service, retail, dress making, food processing, some manufacturing and working alongside husband's in trades. We make a further adjustment for women in rural areas having usage of commons (as recorded for each parish) but no access to other employment. Our participation rate reflects the proportion of adolescent and adult women bringing resources into the household.

Young's tours were more focussed on agricultural employment. In his farm accounts the numbers of maids, men, labourers, boys and servants employed were enumerated. He also asked whether women worked in harvest and hay making and about the winter employment of the poor. Additionally, there are scattered details on manufactures and employment in 36 A document detailing the computation of these participation rates is available from Horrell on request.

37 Our initial focus is on families with the father in a rural occupation but computing national participation rates enables comparability between different sources. We make adjustment for a more diverse occupational structure in section VII below. 
manufacturing towns. We make two computations: the proportion of girls employed as maids on farms and an estimate of the proportion of women working nationally. The latter is achieved by aggregating the farm and parish information into a county picture with a score given for the frequency and type of employment and weighted using county population figures.

Defoe's interest was in investigating trade and manufactures throughout the country. Although a descriptive account it can, with some thought, be converted into a female participation rate. Defoe gives a detailed picture of the type of employment available in nearly every county in England. He documented seaports, coastal shipping and river navigations and the trade they carried. He noted the use of the land through which he passed: wooded, corn, fertile, dairies and sheep downs, and where mining activities occurred. He gave an extensive account of the manufacturing conducted in each county and frequently commented on the extent to which this engaged the local population. Using this information to draw a map of the country locating its chief activities in agriculture, mining, manufacturing, shipping and trade produces a realistic picture of the occupations in each area. Indeed in his introduction, G.D.H. Cole states of Defoe "he is, however, always concerned to record the employment of the common people: and in this especially his work is valuable as presenting by far the clearest picture of the distribution of industries and occupations two hundred years ago".38 But how do we move from these detailed descriptions of activity by county to the proportions of women working? The number of women of working age is assumed to be a constant 25 per cent of the population in each county, the population figure itself resulting from Gregory King's formula for calculating the population in any region

38 Cole, Introduction, to Defoe, Tour thro', (Frank Cass and Co Ltd, 1968 edn.) p.xii. 
from the number of households and hearth taxes taken at Lady Day 1690.39 The different activities mentioned, from heavy involvement in sheep breeding to glass houses and paper mills, are recorded by county. We can then compute the proportion of the total population of England and Wales living in counties with, for example, sheep farming. At this stage we need to make an educated guesstimate about the proportion of working-age women in the population engaged in the activity to give the share of the female population so employed. Summing these shares results in an overall participation rate for working-age women.

Table 6. Women's participation rates from various sources

\begin{tabular}{|c|c|c|c|c|}
\hline Source & Date & $\begin{array}{l}\text { Married } \\
\text { women }\end{array}$ & Single women & All women \\
\hline Statute of labourers & 1351 & & & $\begin{array}{l}\text { Every man and woman } \\
\ldots \text { able of body and } \\
\text { within age of three } \\
\text { score }\end{array}$ \\
\hline $\begin{array}{l}\text { Census of Poor, } \\
\text { Norwich }\end{array}$ & 1570 & $94.7 \%$ & $89.3 \%$ & $\begin{array}{l}91.9 \% \\
\text { (73\% in spinning) }\end{array}$ \\
\hline $\begin{array}{l}\text { Census of Poor, } \\
\text { Ipswich }\end{array}$ & 1597 & $79.0 \%$ & $91.1 \%$ & $\begin{array}{l}83.3 \% \\
\text { (45\% spin and card; } \\
73.3 \% \text { all textile work) }\end{array}$ \\
\hline $\begin{array}{l}\text { Survey of Poor, } \\
\text { Salisbury, Wilts }\end{array}$ & 1625 & $89.6 \%$ & & $71.6 \%$ \\
\hline $\begin{array}{l}\text { Survey of Poor, } \\
\text { Salisbury, Wilts }\end{array}$ & 1635 & & & $\begin{array}{l}49.0 \% \text { of very poor } \\
\text { women only }\end{array}$ \\
\hline $\begin{array}{l}\text { London Church } \\
\text { Courts }\end{array}$ & $\begin{array}{l}1695- \\
1725 \\
\end{array}$ & $60 \%$ & $83.4 \%$ & $72 \%$ stated occupation \\
\hline & $\begin{array}{l}1580 \\
1615 \\
1700 \\
1741\end{array}$ & & & $\begin{array}{l}\text { Spinning only } \\
25.0 \% \\
30.0 \% \\
38.1 \% \\
46.7 \%\end{array}$ \\
\hline
\end{tabular}

39 Richard Stone, 'Some seventeenth century econometrics: public finance', Revue europeenne des sciences sociales, XXVII, 83 (1989). 


\begin{tabular}{|c|c|c|c|c|}
\hline & 1770 & & & $\begin{array}{l}48.7 \% \\
\text { (with other textiles } \\
75.0 \% \text { ) }\end{array}$ \\
\hline Daniel Defoe & $1724-6$ & & & $\begin{array}{l}61.6 \% \text { all women } \\
\text { (19.3\% in full-time } \\
\text { occupations; further } \\
31.48 \% \text { textiles and } \\
10.82 \% \text { seasonal } \\
\text { agriculture only) } \\
\text { Probably lower bound } \\
\text { estimate }\end{array}$ \\
\hline Arthur Young & $\begin{array}{l}1768- \\
1770\end{array}$ & & $\begin{array}{l}33 \% \text { girls aged } \\
15-24 \text { employed } \\
\text { as farm or dairy } \\
\text { maids }\end{array}$ & $\begin{array}{l}61.3 \% \\
\text { (agriculture, textiles } \\
\text { and manufacturing) }\end{array}$ \\
\hline Methodist census & 1781 & & & $54.7-69.3 \%$ \\
\hline Cardington, Beds & 1782 & $\begin{array}{l}70 \% \\
\text { (textiles) }\end{array}$ & & \\
\hline Corfe Castle, Dorset & 1790 & $\begin{array}{l}10 \% \\
\text { (agricultural } \\
\text { area) }\end{array}$ & & \\
\hline $\begin{array}{l}\text { Westmoreland } \\
\text { census }\end{array}$ & 1797 & $69.4 \%$ & $64.3 \%$ & $\begin{array}{l}65 \% \\
\text { (in agricultural area) }\end{array}$ \\
\hline $\begin{array}{l}\text { Frederic Morton } \\
\text { Eden }\end{array}$ & 1795 & & & $\begin{array}{l}56 \% \text { in regular work, } \\
9.75 \% \text { access to } \\
\text { commons only }\end{array}$ \\
\hline Household budgets & $\begin{array}{l}1787- \\
1815\end{array}$ & $65.7 \%$ & & $\begin{array}{l}\text { Maybe } 66 \% \text { over } 10 \\
\text { year olds bring } \\
\text { resources into } \\
\text { household }\end{array}$ \\
\hline $\begin{array}{l}\text { Local census, } \\
\text { Ashton }\end{array}$ & 1816 & $35.9-47.7 \%$ & & $\begin{array}{l}41-52 \% \\
\text { (with occupation) }\end{array}$ \\
\hline $\begin{array}{l}\text { Local census, } \\
\text { Tottington }\end{array}$ & 1817 & $33.6-40.1 \%$ & & $\begin{array}{l}33.3 \%-42.7 \% \\
\text { (with occupation) }\end{array}$ \\
\hline $\begin{array}{l}\text { Local census, } \\
\text { Halstead, Essex }\end{array}$ & 1821 & & $\begin{array}{l}\text { 13.9-83.3\% } \\
\text { (uncertain } \\
\text { classification) }\end{array}$ & \\
\hline $\begin{array}{l}\text { Local census, } \\
\text { Bedford, Lancs }\end{array}$ & $1835 / 6$ & $65.4-73.1 \%$ & & $\begin{array}{l}54.7-62.3 \% \\
\text { (with occupation) }\end{array}$ \\
\hline $\begin{array}{l}\text { Boys' } \\
\text { autobiographies: } \\
\text { mothers with } \\
\text { husband's present } \\
\end{array}$ & $\begin{array}{l}\text { Late } \\
\text { C18th/ } \\
\text { C19th }\end{array}$ & $\begin{array}{l}28.5- \\
35.9 \%\end{array}$ & & \\
\hline National Census & 1851 & & & $43 \%$ \\
\hline
\end{tabular}

Sources: 1570 Pound, 'Elizabethan census'; 1597 Webb (ed) Poor relief; 1625/35 Slack (ed)

'Poverty', 1695-1725 Peter Earle, 'The female labour market in London in the late 
seventeenth and early eighteenth centuries', Economic History Review, 42 (1989); 1580-1770 Craig Muldrew, '"Th' ancient distaff' and whirling spindle': measuring the contribution of spinning to household earnings and the national economy in England 1550-1770", Economic History Review, 65 (2012), for estimates of spinning employment; 1724-6 Defoe (reprint 1928) Tour; 1768-70 Young Six weeks tour; The farmer's tour; Six months tour; 1781 Jacob Field and Amy Erickson, 'Prospects and preliminary work on female occupational structure from 1500 to the National Census', Working paper, Cambridge Group for Population Studies, University of Cambridge (2010); 1782-1790 Saito 'Who worked when?'; 1795 Eden, State of the poor; 1787-1815 Sara Horrell and Jane Humphries, 'Women's labour force participation and the transition to the male breadwinner family, 1790-1865', Economic History Review, XLVIII (1995); 1787 Westmorland census of 1787 (ed.) L. Ashcroft (Curwen Archive texts, 1992) kindly shared by Amy Erickson; 1816 A Census of the Poor of Ashton and Haydock 1816 (Warrington Library, Cheshire County Council); 1817 Tottington, Lancashire - a survey of the poor 1817 (Manchester Public Library); 1821 Census of the Population, Halstead Essex, 1821 (CAMPOP archives); 1836 Survey of the Poor of Bedford Township, 1836 (Bedford Town Book, Wigan Record Office); late C18th/C19th Humphries, Childhood; 1851 Leigh Shaw Taylor, 'Diverse experiences: the geography of adult female employment in England and the 1851 Census', in Nigel Goose (ed) Women's work in industrial England: regional and local perspectives (Local Population Studies, Herts., 2007).

These participation rates suggest that women were extensively involved in the labour market for much of the period, but participation rates declined from 1600 onwards reaching just 43 per cent of all women engaged in regular employment by 1851 (figure 4). At this stage we take no account of the possibility that married women's participation is part-time and 
intermittent. As with child workers, we assume that those who work do so for 250 days of the year. We investigate the consequences of relaxing this assumption in section VI.

The only information we have on participation for the earlier centuries is the Statute of Labourers 1351 (and others) that required all men and women, able of body, and under the age of 60 , to work if so required. This likely led to high female participation rates, but as the Statute applied to people without land and with no other means of support wage labour was by no means universal.40

\section{An adjusted welfare ratio}

We utilise the information on participation rates to capture a welfare picture more representative of the average working family. Men's annual earnings remain the same as previously, but women's and children's are now adjusted by their participation rates which are allowed to vary over time (figure 5).

Figure 5. Family welfare ratio, men on annual pay, women and children on casual pay, participation rate adjusted (250 days worked per year)

40 Judith M. Bennett, 'Compulsory service in late medieval England', Past and Present, 209 (2010). 


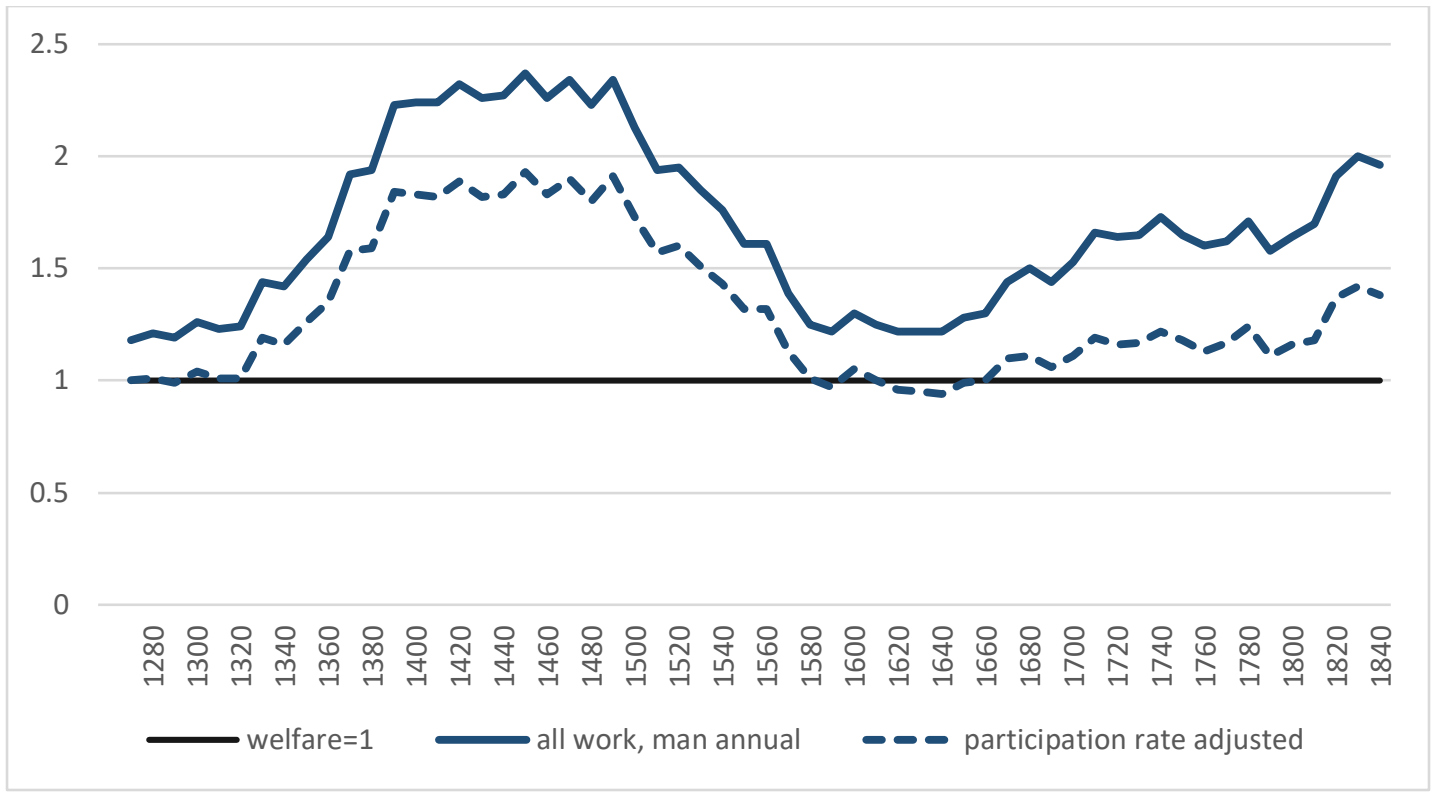

Evidently, most ordinary families were just able to achieve a respectable standard of living in many of the centuries we observe. Indeed, the mid-fourteenth to mid-sixteenth centuries remains highly propitious, but the magnitude and duration of these gains give cause for concern. It is possible, but we believe unlikely, that the 'Golden Age' gains were offset by women and children withdrawing from the labour force: families becoming dependent on male breadwinners while women and children stayed at home to increase domestic comfort and develop their human capital respectively. The ubiquity of both women and children in the farm and household accounts from which we have collected our data speaks against any mass withdrawal, so instead we query the realism of a fixed 250 days of work per year.

V. Relaxing the $\mathbf{2 5 0}$ days of work per year assumption for women and children. 
Following Humphries and Weisdorf, we use trends in the relationship between annual remuneration and casual day rates to track the likely length of the working year over time (figure 6). 41

Figure 6. Casual working days obtained per year by men, 1260-1850



Source: Data on casual days obtained per year by men from Humphries and Weisdorf, 'Unreal wages?'

The resultant days worked reflect the emerging consensus that days of work fell after the Black Death but increased c1600. We apply these trends to estimate expected days worked by women and children on casual contracts for the period 1260-1850 and recalculate the standard of living afforded on a day in the year when the number of days worked per year is

41 Humphries and Weisdorf, 'Unreal wages'; Jacob Weisdorf, 'Day Wages and Their Discontent', unpublished manuscript (2019). 
allowed to vary over time (figure 7). 42 As already articulated, use of annual payments for the man's earnings takes account of the lengthening of his working year.

Figure 7. Family welfare, women's and children's participation rates adjusted and participation rate adjusted with a variable number of days worked per year..

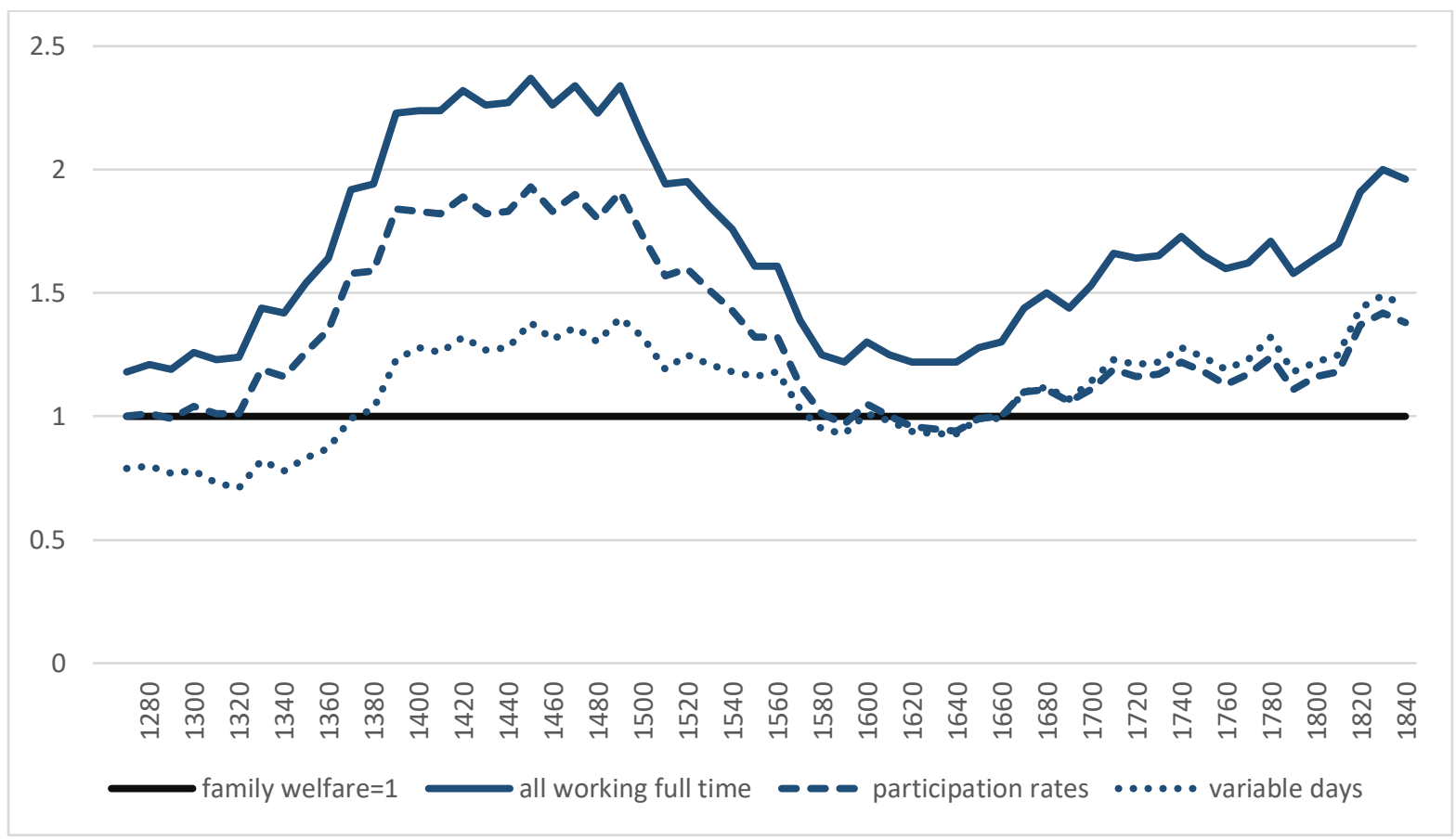

Source: see text

The effect of varying the working year provides a more realistic picture of living standards over the long run. Prior to the Black Death families were eking out an existence at below the respectability level; bare bones survival was the norm. As attested elsewhere, the horrors of the Black Death heralded a 'Golden Age' for those labourers who survived. Even with fewer days of work living standards surged. For much of the period a family could get 25 per cent more than required for respectability alone. Shifts in the types of goods consumed probably

42 See Horrell and Humphries, 'Children's work', for details of this adjustment. 
occurred: people ate more meat, cheese and milk; they possibly made or purchased more leather footwear, woollen clothing, soap and candles; and the additional pasture may have supported more animals for traction, particularly oxen, enabling rural households to complete their agricultural work with less effort and, maybe, in fewer days.43 Tudor turmoil and civil war put an end to these benevolent times. Living standards fell but there was no reversion to pre-plague subsistence. Market expansion, increased trade, improvement in transport, innovation in agriculture and incrementally increasing use of coal for energy, ultimately allowed more continuous economic growth, and a gradual return to the earlier prosperity. But, as found elsewhere, it was only as industriousness gave way to industrial revolution that an ordinary family could expect to see a better standard of living than its forebears. Our data terminates in 1840 so can only hint at this transition, but from 1820 we can see that at last living standards approached the heady heights of the late medieval 'Golden Age'.

Figure 8. Relative contributions to family welfare (adjusted by participation rates and varying number of days in the year worked for woman and children, man on annual contract).

${ }^{43}$ See Broadberry et al, British Economic Growth. 


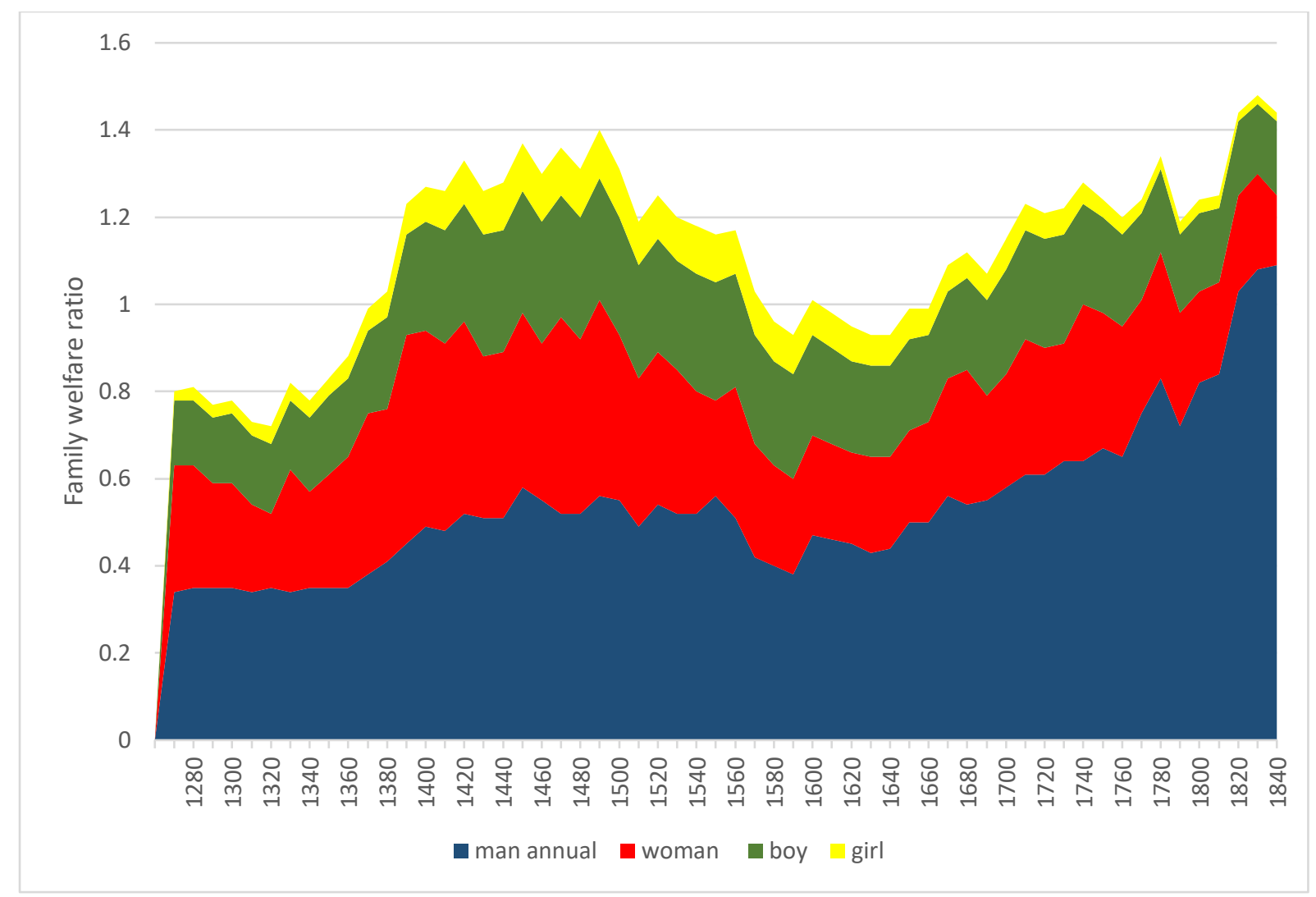

The breakdown of total household material welfare by different members' contributions is illuminating (figure 8). As already seen, the father of a typical family working in agriculture could not alone support his wife and children in a respectable manner until the nineteenth century; contributions from other family members were essential. Under assumptions regarding participation and days worked per year above, the mother made a significant contribution, enough to lift the family above the respectability threshold from the lateeighteenth century, this is consistent with the opportunities offered by a growing economy and the industrious revolution. But it was in the medieval period particularly that married woman appear to have made most impact on their families' material welfare and, indeed, were responsible for much of the dramatic rise in living standards observed. However remember that for the period before 1570, we have been guided by the Statute of Labourers which exhorted all men and women under sixty and physically able to work, and so assumed 
a 90 per cent participation rate for married women. Our suspicion is that while this may have promoted increased participation forthe next three or four decades, the directive faded in force. Moreover, the Statute may not have been widely applied to married women.44 More work is needed on the participation rates of women in families in the medieval period to understand both long-run levels of welfare and the apparent strengthening of female agency evident in the Northern European Marriage Pattern. We remain sceptical that married women were able to undertake the amounts of work thus far assumed so revisit their contribution in Section VI below.

The contributions of children were also important. Children's work was essential to move the family towards a respectable standard of living but only consistently achieved this from circa 1680. The seventeenth century expansion of the economy enabled working families to breach the respectability barrier but it was not until much later that the family could manage without children's labour.

\section{Married women's days of work: further thoughts}

As highlighted above, we have so far worked on the assumption that not only were the majority of married women engaged in some form of market work, they were also able to work the same number of days per year as their husbands. How plausible is this assumption? In fact, it is very unlikely that, in the medieval period at least, women working on a casual basis were able to find anywhere near this amount of work. Prior to the Black Death the types and availability of work for women was limited,45 although the post-plague shortage of labour opened up opportunities for both women and children and a wider range of jobs

\footnotetext{
44 Bennett, 'Compulsory service'.

45 Dyer, Standards of living, pp.131-4.
} 
became available to women by $1379-81$ than previously, women acted only as a reserve army of labour, brought in when male labour supply was inadequate. 46 However, even these gains were probably short lived. In York the peak of women's involvement occurred in 1450.47 The collapse of the cloth industry, the concentration of the luxury trades in London which eroded the prosperity of many provincial towns, and the reduction of land under cultivation, by 1500 imposed more constraints on women's work.48 For much of the medieval period women's work comprised a patch work of intermittent, part-time opportunities, 49 more a grey than a 'Golden Age'.50 The 1600s saw greater restriction. Women were barred from a range of occupations, many were confined to assisting male relatives in their work, or seeking employment as servants in the households of others or engaging in piecework in their own homes.51 The few instances where there is fragmentary evidence on the number of days worked by women in this period illustrate the very casual nature of much of this work. Prior to the Black Death, 1330-9, the numbers of days worked by general labourers at Ebury

46 Dyer, Standards of living, pp.145-6, 229-31; P.J.P. Goldberg, Women, work and life cycle in a medieval economy: women in York and Yorkshire c.1300-1520 (Oxford, Clarendon Press, 1992) pp.100-1; Mavis E. Mate, Women in medieval English society (Cambridge University Press, 1999).

${ }_{47}$ Goldberg, Women, pp.333-7.

48 Dyer, Standards of living, ch.7; Mate, Women.

49 Ibid, p.251

50 Sandy Bardsley, 'Women's work reconsidered: gender and wage differentiation in late medieval England', Past and Present, 165 (1999).

51 Majorie Keniston McIntosh, Working women in English society, 1300-1620 (Cambridge University Press, 2005). 
Manor were recorded. Over the ten years men worked on average 119 days per annum, women just 10 days per year, while in some years women found no work at all.52 Similarly in Cuxham, only men were hired to weed in 1348, but women were engaged for this activity in 1349-50 and again in 1358-9.53 The proportion women formed of the labour force even in the desperate years following the plague was low. Fifteen per cent of the 1,556 named labourers in Essex in 1352 could be identified as married women54 and women were only 20 per cent of those prosecuted for taking too high wages, although they were just over 50 per cent of those who refused compulsory service and just under 50 per cent of those who refused compulsory harvest work under the Statute of Labourers in 1349.55 The increased work availability in the aftermath of the plague appears to have been temporary. On the Sussex estate of Chalvington, large numbers of men were regularly hired for agricultural work, but, in 1441, only eight women were hired (seven of whom could be identified as married) and they collectively worked just 53 days at the harvest, some 6.5 days each.56 Similarly at Porter's Hill in Essex mean employment for men over a year was 7 to 8 days, women 6.5 days.57 Empirical evidence suggests that we are seriously overestimating the amount of paid work done by married women in the medieval period.

52 Ibid, t.4, p.24

53 Mate, Women, pp.28-9.

54 Lawrence R. Poos, A rural society after the Black Death: Essex 1350-1525 (Cambridge University Press, 1991) p.226

55 Bennett, 'Compulsory service'.

56 Mate, Women, pp.30-1

57 Poos, Rural society,p.219 
For the early modern period, we might expect the growing economy to have offered more employment to women. Indeed, a shift in both the demand and supply of female labour is at the heart of de Vries' 'industrious revolution'.58 Industrialisation too expanded opportunities, but as it also demanded increased regularity of work it may well have discriminated against married women who had other responsibilities. The earlier explorations of participation in the commentaries of Eden (1795) and Defoe (1724-6) suggest the breakdown of women's work between formal, regular work and irregular, part-time work. From Defoe's descriptions we identified 19.3 per cent of women in full-time occupations other than textiles and a further 31.5 per cent working in textiles. We also compute that a maximum 42.3 per cent of women may have worked in part-time seasonal agriculture, but some of this might have been alongside textile production. We thus conclude that around 50 per cent of women had regular work, while a further 10 per cent had very intermittent work in 1724-6. Similarly, from Eden's work 56 per cent of all women over the age of ten could have been involved in regular work in 1795 , and a further 10 per cent had access to commons through which they could supplement household resources but no other individual form of support.

For the industrial period, we constructed an estimate of the extent of married women's engagement in paid work for the period 1787-1865 from household budgets.59 If the woman had an occupation recorded we assume she had 'regular' (possibly full time) work, for those women with only some earnings recorded we assume that this represented intermittent or irregular work. This yields 35 per cent of married women in families working regularly and

58 De Vries, Industrious revolution.

59 Horrell and Humphries, 'Women's labour force participation', t.1. 
25 per cent working intermittently. The range of activities undertaken and the intermittent nature of much of this work has been vividly described as an 'economy of makeshifts'.60 Fragmentary evidence on the number of days worked by a few individual women can also be found for this period. Analysis of 84 farm accounts from 1750-1850 finds women to be just 10 per cent of those mentioned as day labourers.61 Female labourers at the Oakes farm outside Sheffield mainly worked on a casual basis for two weeks at hay harvest, but changes in agriculture reduced the availability of even this work.62 Two women in the accounts had reasonably regular employment. From 1772-75 Ann Parkinson worked for 4 1/4 days per week for an average of $291 / 4$ weeks per annum, that is 124 days per year, and from 1837-45 Elizabeth Dyson worked a similar number of weeks in the year but only $33 / 4$ days per week, her annual average being 112 days per year. 63

Le Play's household accounts for four industrial workers' families in the mid-nineteenth century also provide an estimate of the number of days that wives worked annually. 64 Leaving aside the 120-180 days per year these women spent at housework and other tasks, we

60 Alannah Tomkins and Steven King (eds.), The poor in England, 1700-1850; an economy of makeshifts (Manchester University Press, 2003).

${ }_{61}$ Joyce Burnette, 'The wages and employment of female day-labourers in English agriculture, 1740-1850', Economic History Review, 57 (2004).

62 Joyce Burnette, 'Laborers at the Oakes: changes in demand for female day-laborers at a farm near Sheffield during the agricultural revolution', Journal of Economic History, 59 (1999).

63 Ibid.

64 Le Play, Ouvrier. 
focus just on their remunerated activities. One woman worked for 112 days in the year, 52 days making clothes and a further 60 facilitating her husband's work by acting as an intermediary and transporting goods. The others represented the economy of makeshifts. One spent 18 days grazing pigs, 10 days looking after her chickens and a further 20 days brewing a fermented 'pop' drink for sale, some 48 days in total. Another spent 15 days in the year knitting stockings and also worked as a paid childminder for a three year-old. The fourth women spent 15 days in the year grazing her pig.

What emerges from these vignettes of past women's lives is a remarkable degree of continuity. Married women rarely exceeded more than 10-20 per cent of the agricultural labour force and were only employed for a handful of days, although they may have had more regular work in other activities. By the early modern period maybe 40 per cent of married women had regular work and this might comprise 112 to 124 days per annum, but around 20 per cent of wives made much more intermittent contributions to their households' income and worked only 12 to 50 days in the year. Without doubt the assumption that married women active in the labour market worked the same number of days in each year as men is erroneous. We need to adjust the wife's contribution in our representative household. As suggested earlier, the number of days worked by men in the year can be inferred from a comparison of annual and casual remuneration. To some extent the same is true for women but we argue that the female labour market was clearly segmented: annual work was predominantly the preserve of single women and casual work was largely available only to married women. This segmentation reduces any arbitrage that might act to influence rates of pay. Indeed, the days that would have to be worked by women on casual pay to match their single sisters' remuneration in regular continuous work by the late eighteenth century is implausibly high. Furthermore, the implied days of work for women were frequently more than those found for men.However, we can exploit the extent of this overshoot in each period 
to indicate the possible number of days worked by a married woman with regular employment.65 The resulting measure is shown in figure 9 below.

Figure 9. Implied number of days of work available to women 1270-1850

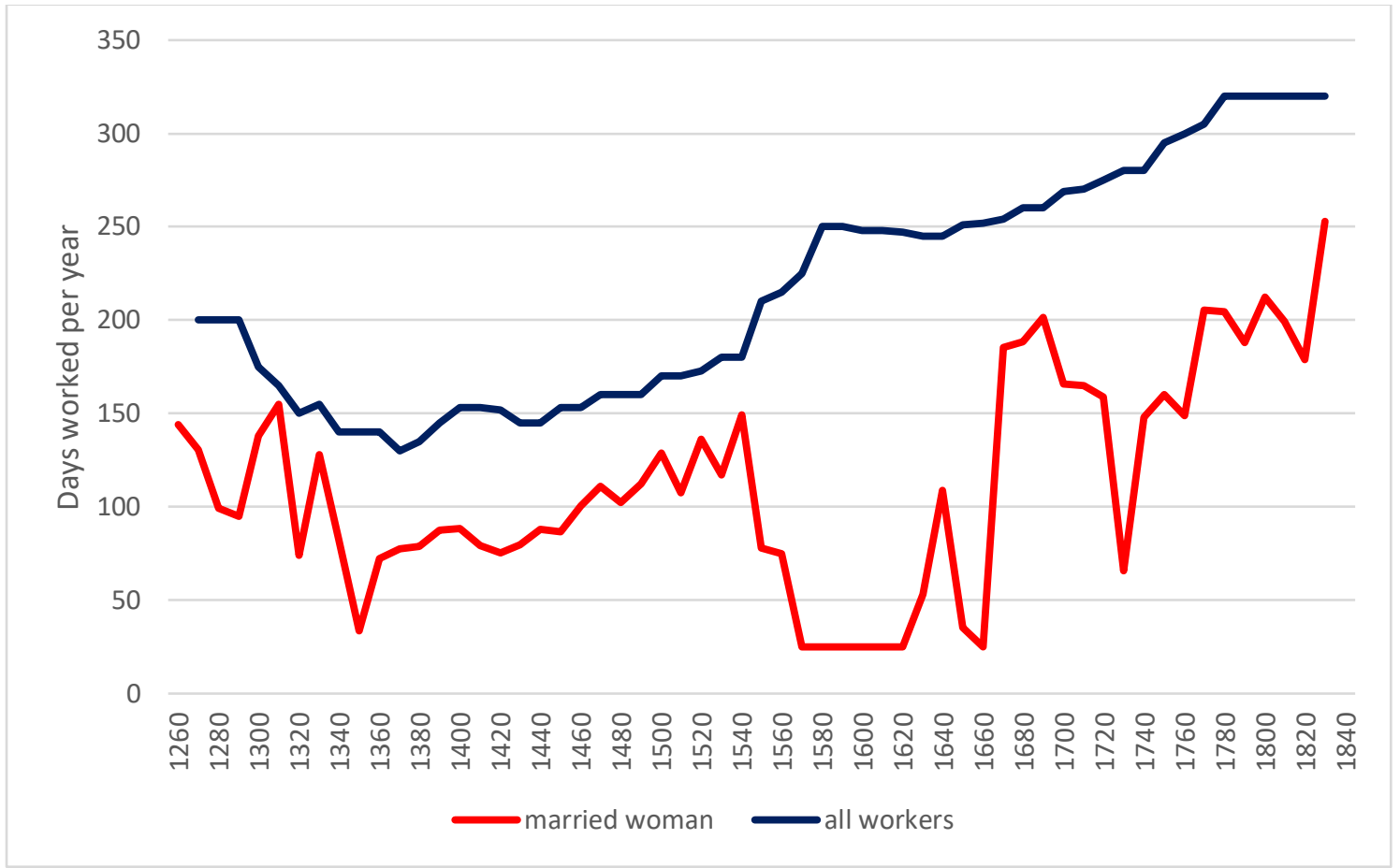

65 Specifically, where the implied work year of women is greater than that for men (in 49 out of 59 decades), we compute the overshoot as a percentage of the men's work year and then take the men's work year less this percentage to indicate the women's work year. This is not a perfect measure of women's days of work but it will pick out movements in the work year that capture the amount of work available. The underlying assumption is that married women would have to work large numbers of days to match single women's remuneration on an annual contract where labour markets are overstocked and, thus, fewer days of work would be actually available. 
How feasible is it that this number of days of work was available to women? Until 1550 , days worked are in line with what is known from medieval sources; days of paid work available to women were highly variable until the Black Death, when labour scarcity resulted in higher and more constant demand for women's labour. The paucity of work available to women from the mid-sixteenth to the late-seventeenth century confirms the severe constraints placed on married women's work noted in the secondary literature.66 Women were barred from weaving in many towns in the fifteenth century, indeed both women and boys under 14 years of age were precluded from weaving wool on looms in Norwich in 1511. Through the sixteenth century, economic and cultural changes reduced the opportunities open to women. Women were denied access to many professions.67 They could not sign contracts, had difficulties in obtaining loans or credit, could not use land as security and were denied the ability to pursue debtors through courts. They could not operate as independent economic agents seizing the opportunities in trade and manufacturing. Women were confined to low paid, intermittent work in overstocked labour markets.68 Subsequent centuries saw increased involvement of women in paid work interrupted perhaps during the English Civil War (164251) and when agricultural change was accompanied by a series of poor harvests (16901740).69

Thus far, the estimated number of days that a woman might work reflects the number available to a wife who could work regularly (figure 9). As we have seen above, not all

66 McIntosh, Working women.

67 Elizabeth Norton, The lives of Tudor women (Head of Zeus publishing, 2016).

68 McIntosh, Working women

69 W. G. Hoskins, 'Harvest fluctuations and English economic history, 1620-1759', Agricultural History Review, 16 (1968) p.23. 
married women were able to undertake this much work, we assume two thirds of the women working. The remaining third worked many fewer days assumed at 25 in the year throughout . We revise the wife's contribution to household income under these more realistic assumptions.70

The consequence of this adjustment for women's contribution to family material welfare reiterates the pattern discerned earlier but at a generally lower level (figure 10). The picture is less rosy. Families existed at around subsistence prior to the Black Death but survivors benefitted from labour shortage.71 Tudor times (1485-1603) saw retrenchment. The growth of London, some commercialisation of agriculture and the expansion of the wool industry were offset by population growth and enclosure which caused upheaval in rural areas. Inflation was rampant as a result of the debasement of the coinage increasing the cost of the respectability basket 143 per cent over five decades, 1540-50 to 1590-1600. 72 As a result, real wages fell. The Dissolution of the Monasteries (1536-40) removed traditional forms of assistance for the poor, heavy rains led to harvest failures (1556-7) and epidemic outbreaks of 'sweating sickness' $(1551-2,1556,1558)$ resulted in extremely high death rates.73 Dubbed the 'Mid-Tudor crisis', 1539-63 witnessed increasing inequality between rich and poor and

70 Specifically woman's welfare ratio for those participating in the labour market in each decade assuming 250 days worked in the year multiplied by $(2 / 3 *$ available days $/ 250)+(1 / 3$ * 25/250)

71 The bare bones basket cost about one half of the respectability basket in this period. 72 See Humphries and Weisdorf, 'Women's work', pp.431-2.

73 John Matusiak, 'Mid-Tudor England: years of trauma and survival', History Review, 52 (2007). 
distress for many at the lower end of the socioeconomic scale. Our representative family suffered in this precipitous decline losing touch with respectability though managing to stay above bare bones subsistence.

Figure 10. Family welfare, showing the adjustments to remuneration from sequentially (a) women's and children's participation rates, (b) allowing women's and children's days of work to vary over time, and (c) women's days of work based on available work and allowing for a proportion of women to be working only intermittently (part time).

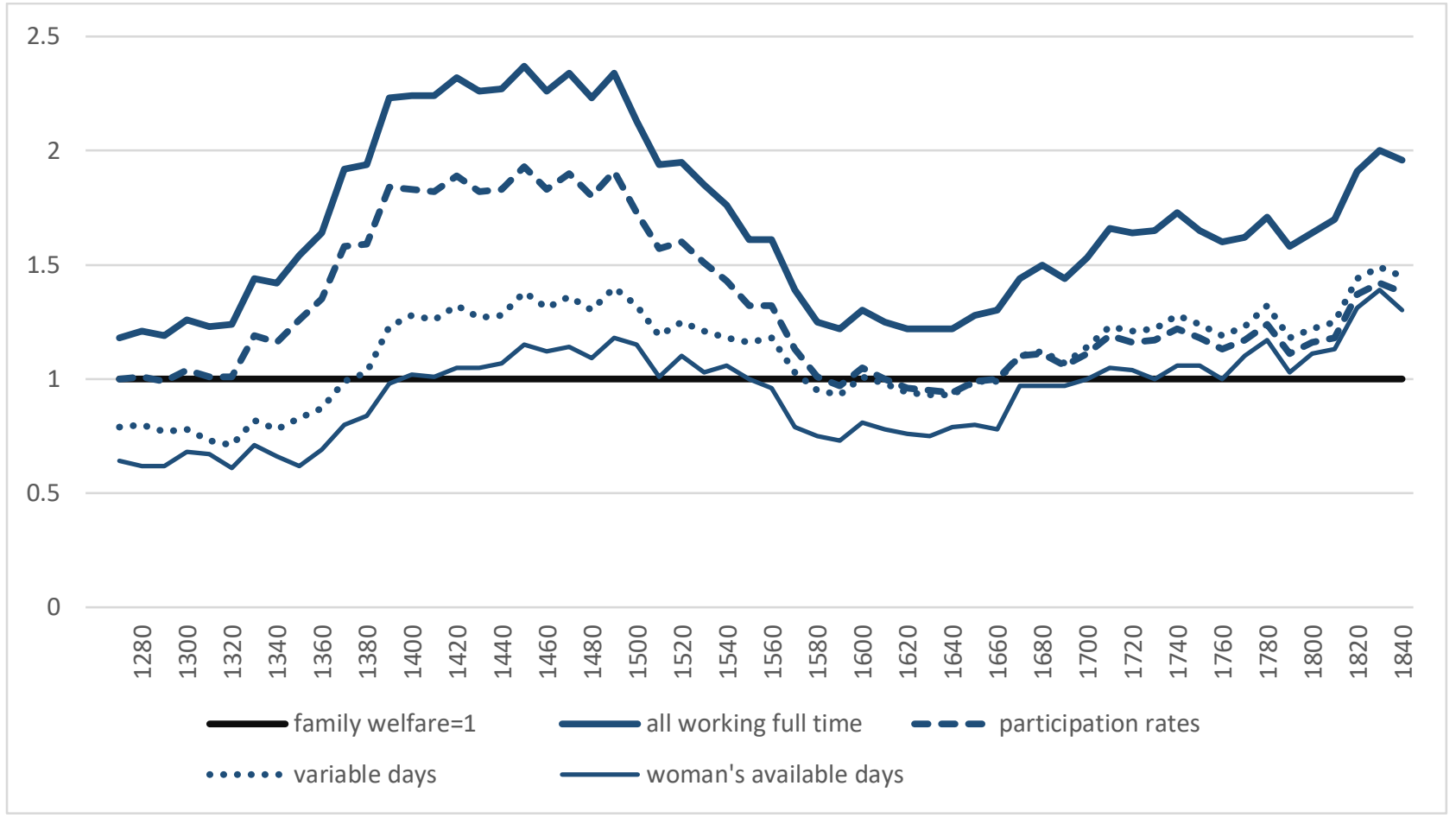

Sources: see text

The situation persisted for a century. Elizabeth I's reign (1558-1603) saw costly wars against the Spanish and Irish and continued socioeconomic distress. Rural depopulation and enclosures caused disorder in agrarian districts and led to three Commissions being set up in the 1630s. Those who lived through the Civil War and Commonwealth suffered ten harvest 
failures in just fifteen years. 74 Not until the late 1600s was the family again able to achieve respectability. Subsequent economic expansion offered greater gains, although this was by no means uninterrupted.75

\section{Family living standards for all ordinary families.}

Until this point, our analysis has focussed on the situation of an ordinary, rural family with the father, mother and son predominantly engaged in agricultural work. As the economy expanded, occupations diversified and the numbers living in towns grew, our rural family became less representative of the population. Indeed, we know that agricultural labourers were one of the lowest paid groups whose wages increasingly lagged behind those of workers in other sectors. 76

We extend our analysis to capture both the premia that might be paid to non-agricultural workers and the shifting occupational structure. We adjust the man's and boy's

\footnotetext{
74 Hoskins, 'Harvest fluctuations', p.18.
}

75 Unemployment and destitution occurred alongside high grain prices 1695-8, 1708-11 were recognised as 'famine years' with deaths from malnutrition, and the winter of 1739-40 was one of the worst known resulting in an embargo on corn export in 1741. Ibid. 76 Sara Horrell and Jane Humphries, 'Old questions, new data and alternative perspectives: family standards of living in the British industrial revolution', Journal of Economic History, 52 (1992); Gregory Clark, 'Farm wages and living standards in the industrial revolution, England 1670-1869', Economic History Review, 54 (2001). 
remunerations accordingly, but leave those of the woman and girl unchanged. Cottage industry and agricultural work often offered similar rates of pay for young children and it is unlikely that a seven-year old girl would be employed in either manufacturing or distribution. Our wife and mother too might be constrained in her ability to take on other forms of workhowever, here our strategy is more pragmatic. We have limited information on either the sectoral distribution of women's employment over this whole period or the rates of pay received for different types of work. We opt to retain detailed knowledge on one sector rather than substituting assumption about others. For both men and boys we utilise the information provided on the sectoral distribution of the labour force by Wallis, Colson and Chilosi for 1540-1780 and the point estimates provided by Shaw Taylor and Wrigley for 1815-19 and 1850-4, the latter interpolated to provide decade shares.77 For the decades before 1540 we project backwards the sectoral shares observed in 1540 . We have detailed information on the premia received by boys in different sectors of the economy from our regression of children's welfare ratios.78 We have less information on men's pay in other sectors. Robert Allen's work

77 Patrick Wallis, Justin Colson and David Chilosi, 'Structural change and economic growth in the British economy before the Industrial Revolution 1500-1800', Journal of Economic History, 78 (2018); Leigh Shaw Taylor and E. A. Wrigley, 'Occupational structure and population change', in Roderick Floud, Jane Humphries and Paul Johnson (eds) The Cambridge Economic History of Modern Britain, vol. 1, (Cambridge University Press, 2014). 78 Horrell and Humphries, 'Children's work'. The amounts are: 0.722 added to the standard of living per day in the year based on a variable number of days worked for construction; 0.21 for manufacturing, 0.226 for service occupations and 0.434 for distribution occupations. Cottage industry is not significantly different to agriculture. The adjustment to pay for the service sector is calculated as the average for service and distribution. 
suggests a mark-up of about 55 per cent for building craftsmen over building labourers. Household budgets for 1780-1860 also record men's earnings by occupation.79 We compute the average premium paid over agricultural work (both high- and low-wage averaged) for mining, factory and casual work.80 Assuming these wage premia to be constant through time, we adjust men and boy's standards of living per day in the year by the sectoral shares and the premia attached to different sectors to obtain an estimate of the standard of living of an ordinary working family in the diversifying economy (figure 11). While living standards were higher throughout the whole time period, the gains are most striking from 1660 as shifts in the occupational structure gathered momentum.

Figure 11. Family welfare: rural family and family representative of all occupational groups (women's and children's work adjusted for participation, a variable number of days worked in the year, and available work for women, as seen in figure 10 above).

79 Horrell and Humphries, 'Old questions', t.1, p.855.

80 Premia are 0.72 for mining, 0.57 for factory and -0.14 for casual work, a sector less well remunerated than agriculture. 


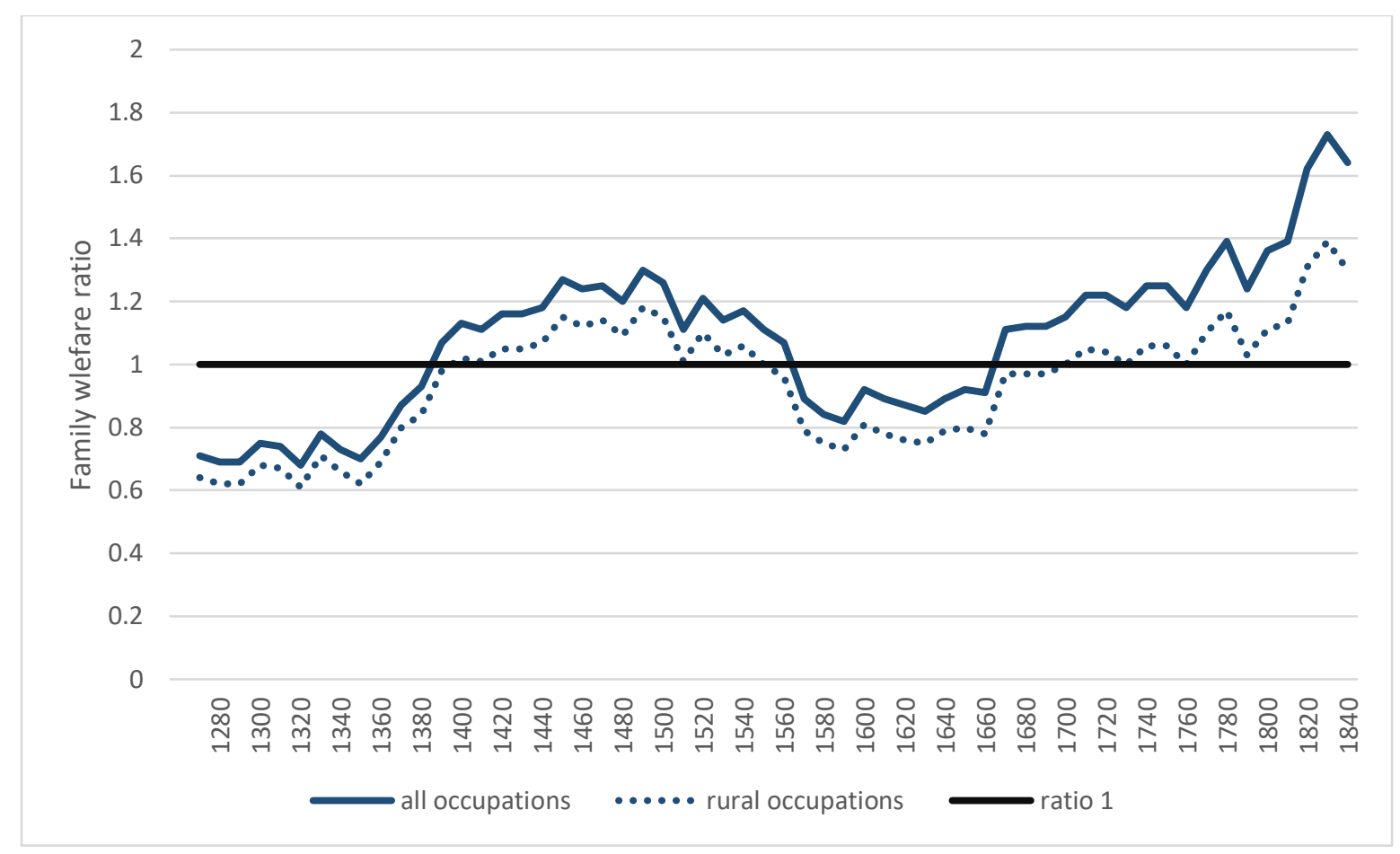

Source: see text

VIII. Family living standards over the long run in historical perspective: discussion and conclusion.

The importance of our work is that it provides a perspective that is not limited to men and their wages, nor marginalised women and children but uses an evidence-based construction of realistic historical families. It provides a firmer grounding from which to discuss the position of a labouring family within the changing economy. Our representative family did enjoy enhanced wellbeing in the 'Golden Age' for labour that followed the Black Death but this was transitory. More continuous albeit gradual improvement occurred after the midfifteenth to mid-sixteenth century dislocation. How does this fit with the meta-narratives of economic growth and demographic transition over the long-run?

A useful initial comparison can be made with the trajectory of the wages of a farm labourer working 250 days in the year and also supporting a family of five (figure 12). While our rural 
family manages a slightly higher standard of living before the Black Death, both estimates indicate that barebones subsistence, rather than respectability, was the lot of the pre-plague population. The subsequent labour shortage enabled the subsistence barrier to be breached and, on both measures, the high wage economy emerged.81 But here the trajectories differ. The work and contributions of family members other than husbands and fathers ensured the precipitous decline back to pre-plague penury was in large part avoided and then enabled the family to share in the gains the economic expansion brought from the mid-sixteenth century onwards. Women and children were mainstays in providing labour for the take-off in the woollen and small metal goods industries, and they made up the additional labour on which the industrious revolution relied. If we allow for diversification as the economy expanded with increasing shares of the labour force working outside agriculture, the welfare of the family is additionally smoothed. While it took industrial revolution to restore the post-plague prosperity, living standards never again dropped below the respectable level.

\footnotetext{
${ }^{81}$ At its medieval peak our family achieved a welfare ratio of 1.4 , this is also the welfare ratio implied from the 150 days work needed to maintain a family equivalent to 3.25 adults on a respectable basket found for farm labourers and building workers, see R.C. Allen and J. L. Weisdorf, "Was there an "industrious revolution" before the industrial revolution? An empirical exercise for England, c.1300-1830 ', Economic History Review, 64 (2011). Calculated from figures 1 and 2 . The trajectory of our family welfare measure also fits much more closely with the welfare achieved by actual families shown in figure 3 above. The exception are Muldrew's spinning families but their earnings have been shown to be significantly overestimated, see Jane Humphries and Benjamin Schneider, 'Spinning the industrial revolution', Economic History Review, 72 (2019).
} 
Figure 12. Family standard of living (welfare ratio) rural occupations and all occupations compared with family welfare ratio from male farm workers' casual pay and real GDP per capita

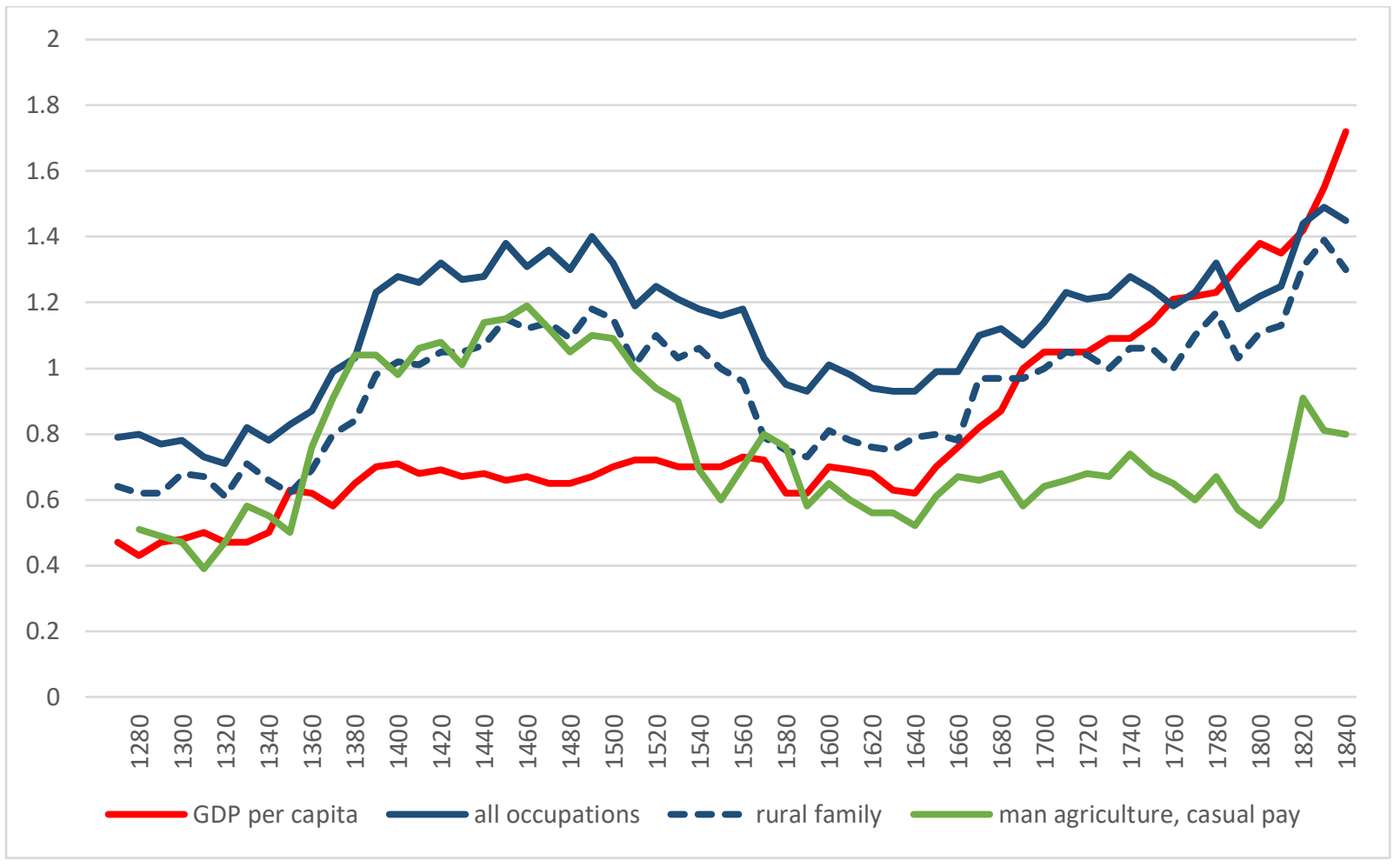

Sources: GDP per capita (indexed at 1700=1), Broadberry et al, British Economic Growth; male farm worker from Clark, 'Long march', day rates multiplied by 250 relative to cost of Allen respectability basket for family (x 3.5); family work, see text.

The findings from our study do not disrupt the meta narrative of long-run English economic growth, nor the emergence of the high wage economy, but it is noticeable that our family income series provides a better fit with the growth in output (GDP per capita) than the established series for male wages and that it does so through the inclusion of women and children's contributions to family welfare. The high wage economy is reached not through the endeavours of a male breadwinner working 250 days each year but, instead, by the 
opportunities offered to and taken up by the 'secondary' earners who frequently carried the family over a threshold of comfort or enabled it to cling onto something like respectability in hard times (figure 13). An ability to mobilise the labour of women and children emerges as a key mechanism underlying England's development and one that that may well be particularly relevant in a comparative context. Moreover, since our discipline has been increasingly enamoured of the idea that the Industrial Revolution was a product of scientific advancement, the post-1600 continuous increase in the length of the working year for male workers and the intensification of this growth in the run-up to industrialisation, provides a salutary reminder of the relevance of other factors. When we add the industriousness of women and children to the increasing labour input from men, the part played by working people and the costs they shouldered are brought into sharper perspective. It was the blood, sweat and tears of our family workers in their quest for respectability that turned scientific acumen and inventiveness into the widening flow of goods and services that presaged and then marked the industrial revolution.

Figure 13. Family members' contributions to family standard of living: rural family, man on annual contract, woman (married) working available days, adjusted for women's and children's participation rates. 


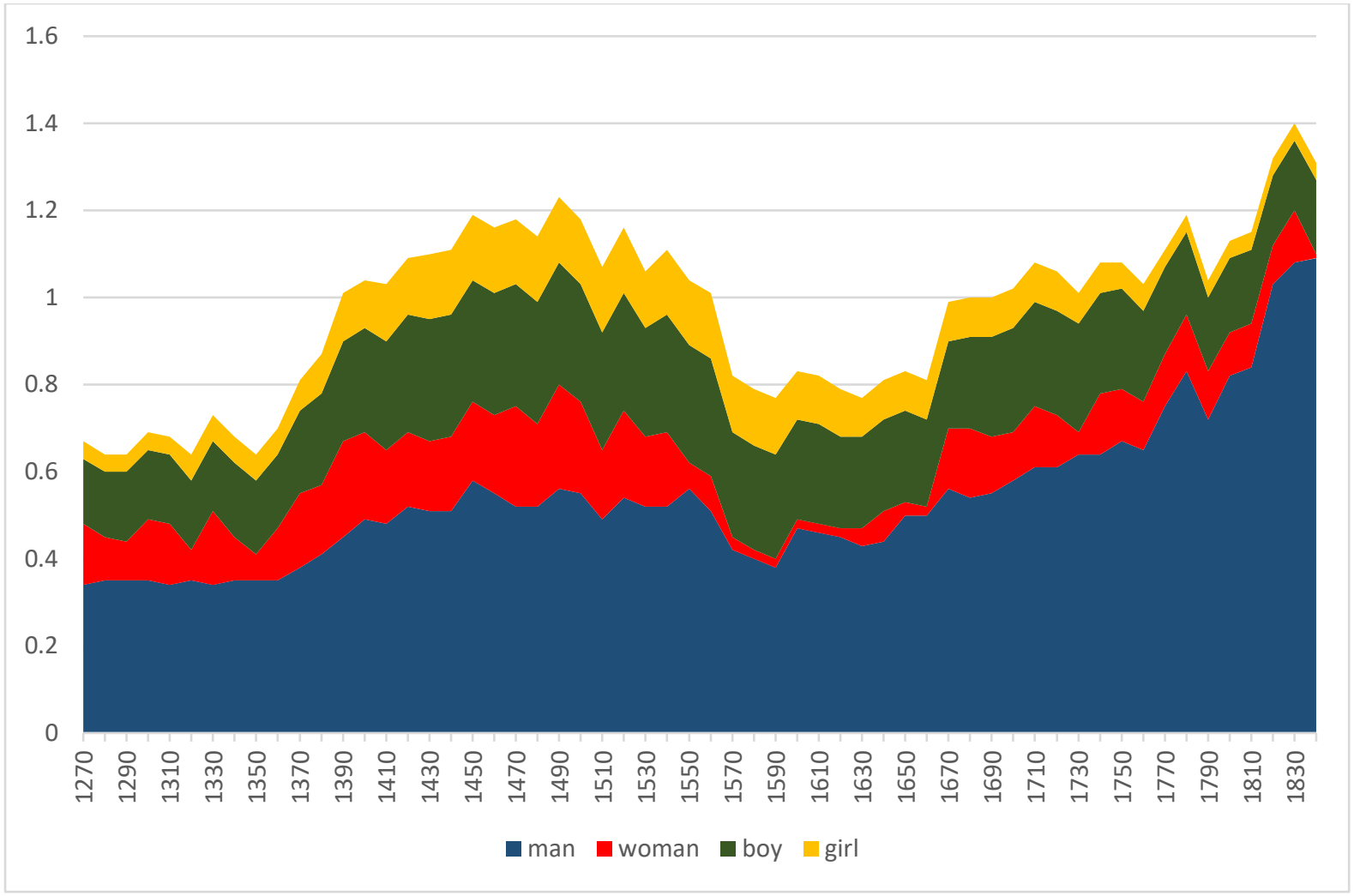

Source: see text

While the present analysis does not enable us to delve further into these mechanisms, it highlights areas for future research. The emergence of the Northern European Marriage Pattern has been attributed to young women deferring marriage when post-plague prosperity afforded them high wages and a degree of financial independence: 'girl power'. 82 Our data find improved earnings for those in casual work, but not for those of young women in service. . 83 Conversely, our data has highlighted increased contributions from women and children, which may have enhanced their status within the family and led to their empowerment more generally, while simultaneously promoting the economic viability of marriage. Our findings also open up questions surrounding the role of human capital 82 de Moor and van Zanden, 'Girl power'.

83 See Humphries and Weisdorf, 'Women's wages'. 
acquisition by children in this period and the relationship of youth labour markets to adult ones.

Looking at growth through the evolution of family incomes, identifies gaps in chronology as well as a mainstream heedless of its surrounding case studies. For example, the loss of women's earnings in Tudor times emerges as clearly detrimental to household welfare, yet this bleak phase remains by and large overlooked in studies of long-run growth while demonstrating yet again how women's activities, even when documented in the historical literature, fail to be integrated into the grand narrative. Early modern growth is accompanied by a tendency towards a male-breadwinner family, but this should not overshadow the importance of the industriousness of women and children in its early phases. Before the nineteenth century any high wage economy was a high family wage economy. Understanding this may help in understanding its causes and consequences. 